\title{
Adjustment of the Yielding System of Mechanical Rock Bolts for Room and Pillar Mining Method in Stratified Rock Mass
}

\author{
Krzysztof Skrzypkowski $^{1, * \mathbb{D}}$, Waldemar Korzeniowski ${ }^{1} \mathbb{D}$, Krzysztof Zagórski $^{2}$ and $^{-}$ \\ Anna Zagórska ${ }^{3}$ \\ 1 Faculty of Mining and Geoengineering, AGH University of Science and Technology, Mickiewicza 30 av., \\ 30-059 Cracow, Poland; walkor@agh.edu.pl \\ 2 Faculty of Mechanical Engineering and Robotics, AGH University of Science and Technology, \\ Mickiewicza 30 av., 30-059 Cracow, Poland; zagkrzys@agh.edu.pl \\ 3 Institute of Geological Sciences, Polish Academy of Sciences, Senacka 1, 31-002 Cracow, Poland; \\ ndzagors@cyf-kr.edu.pl \\ * Correspondence: skrzypko@agh.edu.pl
}

Received: 10 March 2020; Accepted: 20 April 2020; Published: 21 April 2020

\begin{abstract}
The article presents a novel yielding mechanism, especially designed for the rock bolt support. Mechanical rock bolts with an expansion head and equipped with one, two, four and six dome bearing plates were tested in the laboratory conditions. Furthermore, in the Phase2D numerical program, five room and pillar widths were modeled. The main aim of numerical modeling was to determine the maximal range of the rock damage area and the total displacements in the expanded room. The models were made for a room and pillar method with a roof sag for copper ore deposits in the Legnica-Głogów Copper District in Poland. Additionally, in the article a load model of the rock bolt support as a result of a geomechanical seismic event is presented. Based on the results of laboratory tests (load-displacement characteristics), the strain energy of the bolt support equipped with the yielding device in the form of dome bearing plates was determined and compared with the impact energy caused by predicted falling rock layers. Based on the laboratory tests, numerical modeling and mathematical dynamic model of rock bolt support, the dependence of the drop height and the corresponding impact energy for the expanded room was determined.
\end{abstract}

Keywords: rock bolt support; yielding; stratified rock mass; load model of rock bolts

\section{Introduction}

Currently several mines in Poland are being operated at depths greater than $1000 \mathrm{~m}$. At such levels, the rock mass can be highly stressed causing an increase in the frequency of natural hazards, especially rock bursts. Of particular importance is the aspect of deposit protection in mining methods, in which the increase in extraction rate, labor efficiency and reduction of production costs should be accompanied by a reduction in mining losses. The sources of operational losses in the room and pillar methods are barrier pillars and, above all, technological pillars, that constitute the function of a natural roof support and protect excavations since the moment of bed cutting up to the stage of liquidation the last rows of pillars becoming a part of the abandoned area. The basic way to minimize the mining losses is to cut the technological pillars to residual dimensions, while maintaining the required load capacity of the rock bolt support. The importance of this issue, results from the fact that the rock bolt support are used in the conditions of the stratified rock mass, and the occurrence of geomechanical seismic events or technological resulting from the use of explosives for the mining technology. In order to ensure full functionality of the excavation, the loads carried by the support interaction system with 
the rock mass must be less than permissible, and the displacements may not exceed the predicted amounts. The bolt support should strengthen the rock mass by connecting individual layers of rocks into one strong layer or suspend the weaker strata to the stronger part of the rock mass above the bolted zone. In addition, the bolt support should stop displacement of fractured rock materials [1]. The rock mass's ability to energy accumulation and then its release in the form of dynamic phenomena requires that the rock bolts, should be characterized by a high loading capacity and high susceptibility to tensile, which excludes their breaking even in the case of intensive momentary displacement of thick roof layers.

In the conditions of the stratified roof, which tends to separate individual layers, the use of the yielding rock bolt support, contributes to the takeover of falling rock masses, thanks to which the excavation can retain its functionality for longer. In world mining, solutions of yielding bolt supports are characterized by their large deformation properties, which means that the bolts can elongate to limit the axial load, and transfer more work on the rock mass [2-4]. In the conditions of stratified rock mass and geomechanical seismic events, the most important parameter of the bolt support is not its load capacity, but rather the ability to perform work during the dynamic deformation of rocks surrounding the excavation. In order to stop rock masses moving into the excavation without serious damage, the bolt support must absorb the transmitted impact energy $[5,6]$.

Yielding rock bolt support can be made by changing the profile of the bolt rod geometry. Ortlepp et al. [7] stated that, Duracable bolt (shape of sine wave) under quasi-static loading conditions, displayed a particularly smooth response with the resistance rising to $100 \mathrm{kN}$ before sliding commenced. After some $45 \mathrm{~mm}$ of yield the resistance load dropped to a steady value of $70 \mathrm{kN}$, consuming energy at $7 \mathrm{~kJ}$ per $100 \mathrm{~mm}$ of displacement. St-Pierre et al. [8] examined Modified Cone Bolt (bolt rod with a conical end) and determined that, cone displacement can vary from less than $10 \mathrm{~mm}$ to as much as $150 \mathrm{~mm}$. Li [9] proposed a $D$ bolt, which has two shapes: paddle and wiggle. The $D$ bolt with a $1 \mathrm{~m}$ deformable section reaches deformation at more than $150 \mathrm{~mm}$. Additionally the average cumulative energy and ultimate elongation of the $0.795 \mathrm{~m}$-long samples ( $D$ bolt) equal $38 \mathrm{~kJ}$ and $133 \mathrm{~mm}$, respectively.

Another way may be to use an additional element, an absorber, inside the bolt hole. Charette and Plouffe [10], used an absorber in the Roofex bolt and they found that a sliding length setting of $600 \mathrm{~mm}$ can allow up to about $25 \mathrm{~kJ}$ of energy dissipation. Varden et al. [11] used a yielding device for Garford bolt. When the bolt is subjected to a ground movement the bolt is forced through the yielding device and elongates. The Garford bolt is characterized by total energy absorption up to $70 \mathrm{~kJ}$ and displacement of more than $275 \mathrm{~mm}$. Wu and Oldsen [12] tested Yield-Lok bolt equipped with a polymer cover. They found that Yield-Lok bolt is able to produce up to $250 \mathrm{~mm}$ of displacement per impact with energy input $16.4 \mathrm{~kJ}$. Wang et al. [13] tested rock bolt that consisted of a drawing rod and a drawing die. The ultimate displacement of the bolt is in the range from $140 \mathrm{~mm}$ to $160 \mathrm{~mm}$. He et al. [14,15] designed and tested $\mathrm{He}$ bolt, which is equipped with a cone and the elastically-deformed segment of the sleeve. The elongation is as long as $300-1000 \mathrm{~mm}$ and is realized by the relative displacement of the cone-shank assembly with respect to the sleeve cylinder. Wu et al. [16] tested TCC yielding bolt, which consist of a steel rod and two additional anchors and is characterized by elongation equal from 386 to $754 \mathrm{~mm}$ for 2500-5000 mm-long bolts. Yokota et al. [17] designed DC-bolt, which possesses both the high loading capacity and the deformable capacity. The DC-bolt is mainly comprised of four components: a smooth bar, a threaded bar, an end anchor whose diameter is larger than the smooth bar and a ring which does not attach to the smooth bar (when the ring was broken at the $200 \mathrm{kN}$ of the pull-out force, the displacement at the rock bolt head was $135 \mathrm{~mm}$ ). 
A cheap, fast and effective way to make the bolt support more yielding is to install a special device on the bolt rod placed between the roof and the bearing plate. Hao et al. [18] tested a new energy-absorbing rock bolt which mainly contains a rebar, a sleeve tube, and steel balls. The proposed rock bolt has high elongation and energy-absorbing capacity equal: $298 \mathrm{~mm}$ and $123 \mathrm{~kJ} / \mathrm{m}$. Lu et al. [19] and Sun et al. [20] proposed a steel yielding tube, which has a height change range of about $30 \mathrm{~mm}$. Korzeniowski et al. In [21], the authors designed a novel deformable component which involves on the incomplete compression of the disk springs, and plastic strain of the rock bolt bearing plates at the side of the bolt rod head. Such a solution means that the rock bolt can be displaced by about $30 \mathrm{~mm}$. Chen et al. [22] proposed a new energy-absorbing $R$-bolt that uses high damping rubber. Additionally, high-damping rubber can consume more energy under stronger impact. Dai et al. [23], designed a split steel sleeve with a wall thickness of $4 \mathrm{~mm}$ and length of $150 \mathrm{~mm}$, which was fabricated from Q235 mild steel ductile metal. Furthemore, Dai et al. [24] stated that, the constant resistance value of the splitting energy absorber is as high as $125-150 \mathrm{kN}$, while the energy-absorption efficiency is $0.111-0.127 \mathrm{~kJ} / \mathrm{mm}$.

The mentioned forms of yielding, cause, that the bolt support is able to deform in the range of several dozen to several hundred millimeters. In the construction solutions, making the rock bolt support more yielding, there is no design consisting of at least two domed bearing plates. Therefore, in this article, a rock bolt support equipped with domed bearing plates, which are a form of making the bolt support more yielding, contributing to the increase in the scope of its displacement, is proposed. This is especially important in the case of expanding the room as a result of cutting technological pillars. The rock bolt support used in the underground copper mines of Legnica-Głogów Copper District (LGOM) in Poland protects underground excavations in the conditions of stratified rock mass and dynamic loads. Both flat and profiled bearing plates with round, triangular, square and hexagonal profile are used. However, there are no mechanical bolt supports equipped with mechanisms of yielding, which, without interfering with the profile of the bolt rod or changing the steel grade, would be able to immediately improve the displacement characteristics of the support.

\section{Copper Deposit Exploitation by Means of Room and Pillar Method in the Conditions of Dynamic Loads and Stratified Rock Mass}

\subsection{The Influence of Technological Seismic Event on the Bolted Roof}

Exploitation of the deposit by means of rock blasting technique has a positive importance in the aspect of ore extraction and in the fight against the threat of tremors arising in the upper floor layers, however, there is the possibility of harmful effects on the stability of the bolted roof in adjacent excavations. First of all, damages to the roof excavation may consist of an increasing number and extent of fractures [25-27]. In addition, loose irregular rock blocks may form in the roof space, which may move into the interior of the excavation. Often, as a result of tremors, the bolt support is additionally loaded through the weight of roof rocks, and in critical situations a roof rock falls may occur. For the room and pillar mining methods, breaking the continuity of roof layers, in particular, when it performs a supporting role, requires complete reconstruction of its section to create a new support structure in the roof. The high compressive strength of the dolomite rocks in the Polish underground copper ore mines in the LGOM (Figure 1a,b), as well as, the need to relieve the roof rock mass by means of blasting works, often causes a series of a large amount of explosives to be detonated simultaneously.

These blasting charges in a single room face, reach a mass of several dozen to several hundred kilograms of explosive (Figure 2a-c), while in a group blasting, involving the firing of several scattered or neighboring rooms simultaneously, this value can reach several tons of explosives. Blasting of such a large number of explosives near the room, protected by the bolt support, can cause a series of invisible fractures in the surrounding rock mass. 


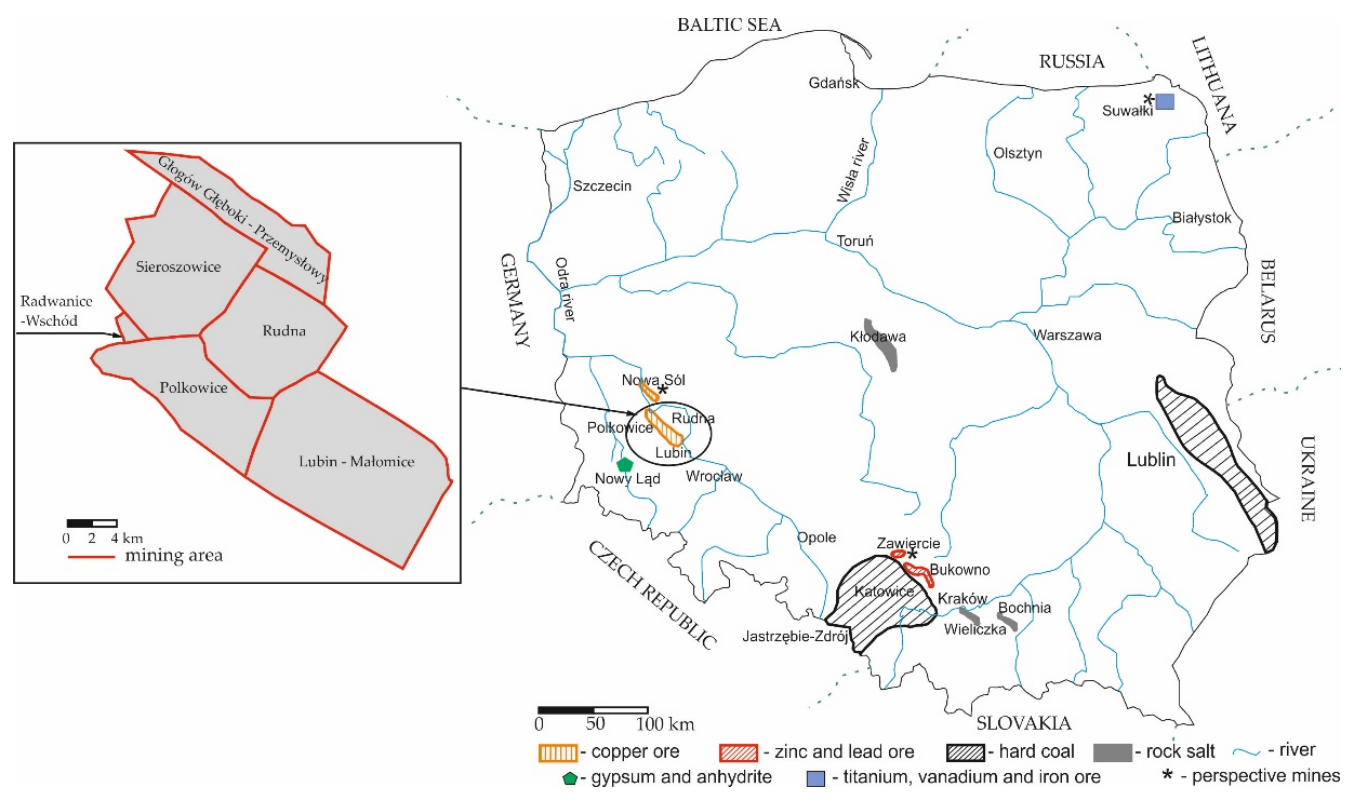

(a)

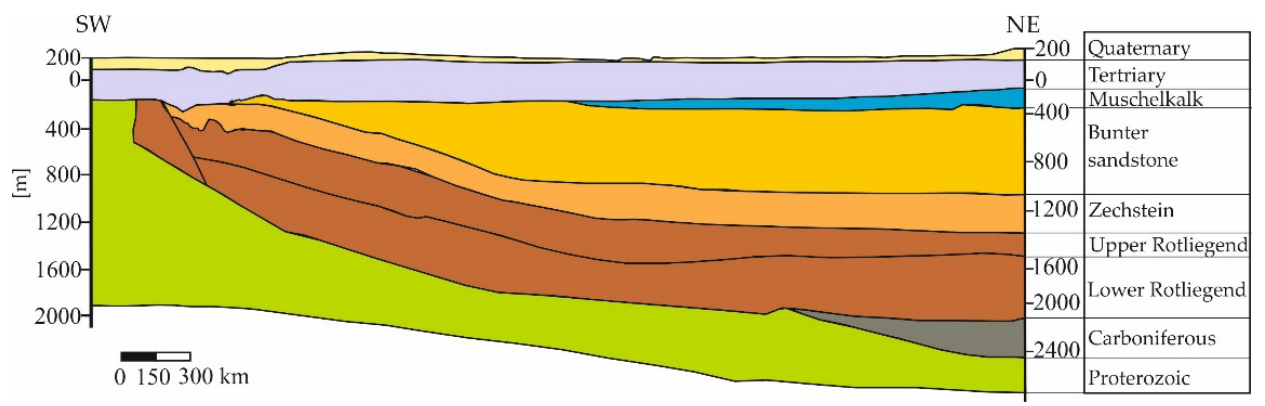

(b)

Figure 1. Location of current and prospective underground mines in Poland with particular emphasis on Legnica-Głogów Copper District: (a) location of mining areas; (b) geological cross section of copper ore deposit in Fore-Sudetic Monocline.

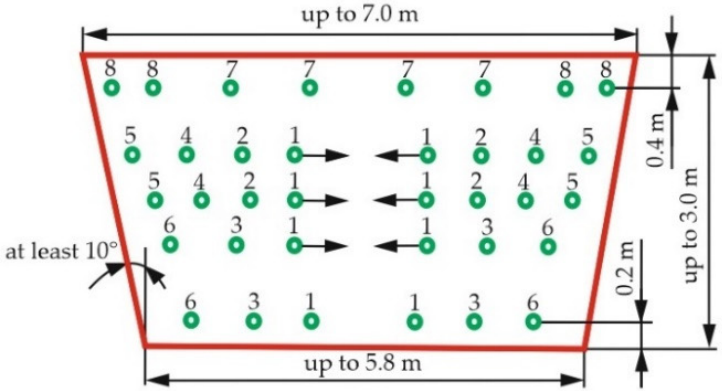

(a)

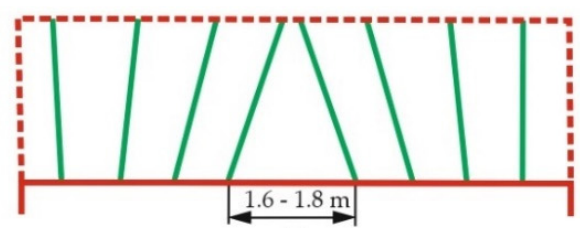

(c)

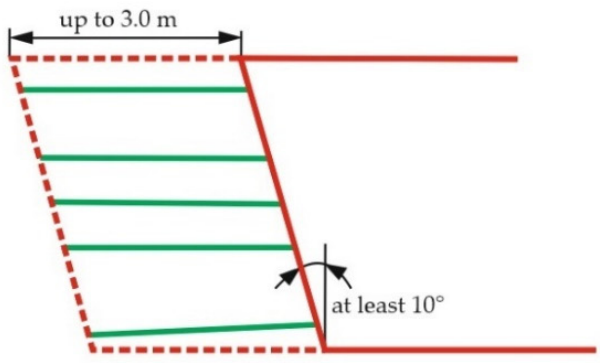

(b)

- - blasting holes

1 ....8 - the delay number of detonators

Maximum charge for one blasting hole: $2.7 \mathrm{~kg}$ (dynamite)

Maximum charge for one blasting hole: $5.0 \mathrm{~kg}$ (emulsion material)

Number of holes: 36

Figure 2. An example of the arrangement of blast holes in the room: (a) cross section; (b) side view; (c) top view. 
For the room and pillar method with roof sag, the weakening role of these fractures becomes partially visible only as the room deformation progresses so that finally, it may be manifested as roof falls. According to Polish mining regulations [28,29], a fall of roof in the excavation supported by rock bolts, in mining plants extracting copper, zinc and lead ore is understood as an unintentional, gravitational displacement to a rock mass excavation, as a result of the fall of roof rocks to a height equal to or greater than the length of primary rock bolt support, causing total or partial loss of functionality or safety of use of the excavation. In the event of rock fall to a height less than the length of the bolt support, we are dealing with a shallow roof fall down. For underground copper ore mines in the LGOM, the shallow roof falls are typical, usually covering one or a few layers of carbonate rocks. According to technological experience the seismic events or loosening of clay layers during drilling of bolt holes with water flushing are usually the reason for such shallow roof falls [30]. A characteristic feature of carbonate rocks constituting the roof of the room excavations is their stratified construction. In the roof, there are often planes of weakened coherence at the contact of layers of various mineral composition. The thickness of stratified rock mass depends on the intensity of the structures isolating individual layers (Figure 3a,b). In particular, the following structures can be distinguished:

- Mineral veins filled with gypsum, anhydrite, calcite and barite, with a thickness from $1 \mathrm{~mm}$ to $30 \mathrm{~mm}$ (Figure 3c,d);

- Clay layers between with a thickness from $1 \mathrm{~mm}$ to $10 \mathrm{~mm}$ in a carbonate rocks, usually horizontal and often wavy. The filling material is clay and carbonaceous substances very plastic and soft (Figure 3e);

- $\quad$ Stylolite, whose amplitude is variable and ranges from $1 \mathrm{~mm}$ to $150 \mathrm{~mm}$ (Figure 3f).

The degree of fissure filling is significantly influenced by aqueous solutions migrating in the rock mass, which dissolve and wash the fissure filling material. The intensity of occurrence of structures emphasizing stratification, varies greatly in the bolted roof areas. This variability can be observed within one exploitation field, and even in the vicinity of two rooms. The thickness of layers in carbonate rocks is very diverse. It is possible to distinguish between very thin-bed constructions with a thickness of $10 \mathrm{~mm}$ to $100 \mathrm{~mm}$, medium-bed constructions with a thickness of 100 to $300 \mathrm{~mm}$ and thick-bed constructions with a thickness of 300 to $1000 \mathrm{~mm}$ for a construction with a very thick-bed construction, above $1000 \mathrm{~mm}$ [31].

One of the measures of the dynamic impact of tremors on the excavation may be the maximal peak particle velocity (PPV) on the contour of the excavation (surface of the bolted roof). The measurement results were recorded by specialized seismic-acoustic equipment, creating dynamic criteria for the damage or destruction of the excavation [32-35]. In order to check the behavior of the bolt support under the influence of dynamic load, caused by the detonation of explosives, Korzeniowski (2006) designed a special test stand in one of the copper ore mines in Poland [36]. In the forehead of the room, single explosive charges of increasing mass were blasted (Figure 4a). In the forehead, 20 blast holes with a diameter of $51 \mathrm{~mm}$ and a length from 2.0 to $3.2 \mathrm{~m}$ were drilled. Using a rotary percussion drill, vertical auxiliary holes with a diameter of $200 \mathrm{~mm}$ and a depth of $0.5 \mathrm{~m}$ in the roof, were drilled. In the bottoms of these holes, rock bolts were installed, to which steel cylinders were then tightened, equipped with measuring sensors (Figure $4 b$ ). Five holes were located in the roof axis at a distance of 2 to $25 \mathrm{~m}$ from the forehead. During the experiment, the vibration velocity of rock particles and bolts stimulated by an elastic wave, measured along one radius in a rock medium and mine atmosphere, was measured. The recording was carried out at each measuring station, in which there were three sensors for converting the displacement of rock mass particles into digital signal. Based on the research [36], a relationship between the amount of explosive used and the induced peak particle velocity of the rock mass was found. In addition, the range of variability of the additional force loading the rock bolt support, as a result of the blasting works in the exploitation forehead was given. It was found that the value of the additional force did not exceed $4 \%$ of the required bolt load capacity of $100 \mathrm{kN}$. The mine tests, regarding the impact of tremors, caused by the use of explosives for mining the orebody, indicate 
that a PPV equals to $0.2 \mathrm{~m} / \mathrm{s}$ may damage the excavation, while a PPV equals to $0.6 \mathrm{~m} / \mathrm{s}$ may have a destructive character of the excavation [33].

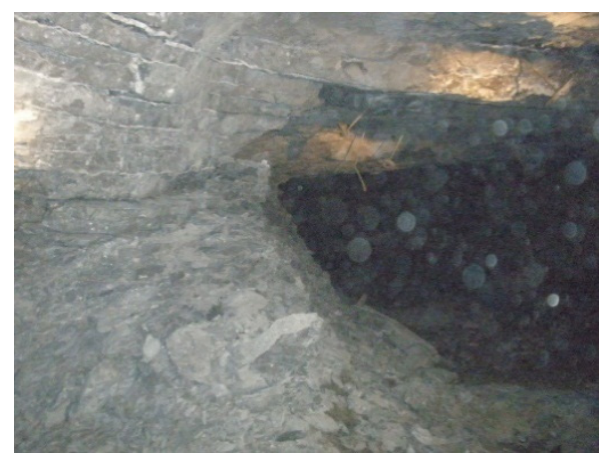

(a)

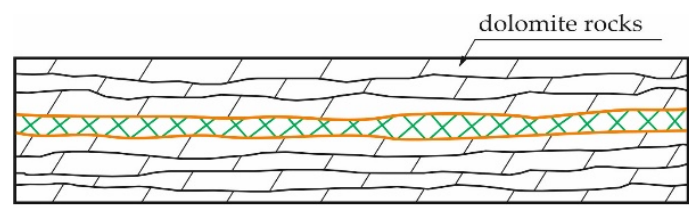

$\overline{X X}$ - mineral vein filled by crystalline gypsum

(c)

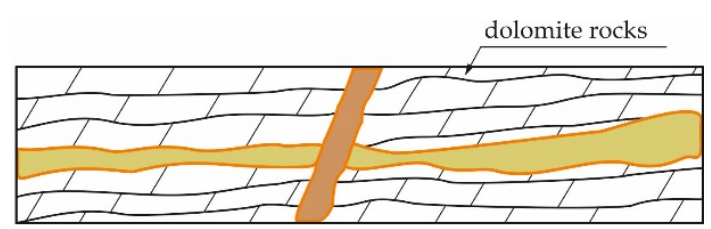

- flat layer filled by clay-carbon minerals

- inclined layer filled by clay-carbon minerals

(e)

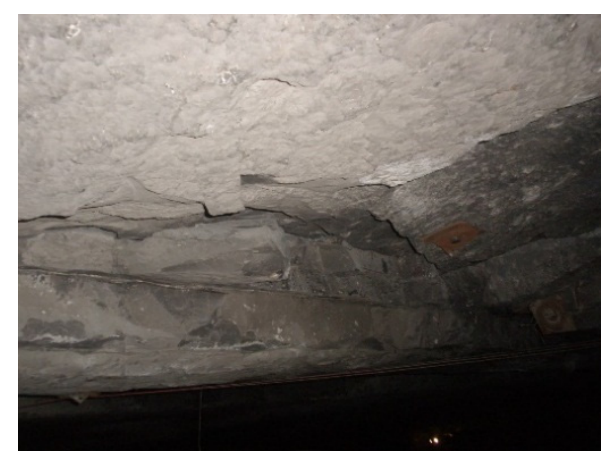

(b)

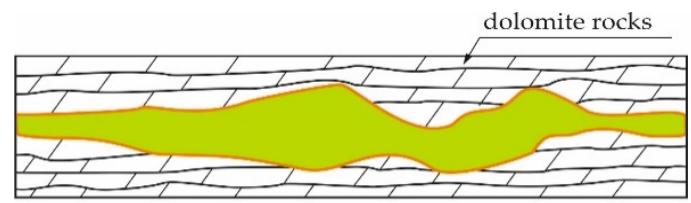

- mineral vein filled by anhydrite

(d)

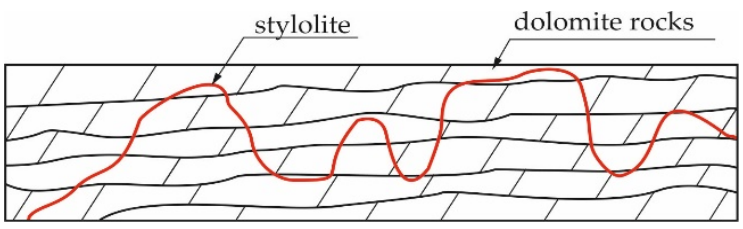

$(\mathbf{f})$

Figure 3. Characteristic structural forms of carbonate rocks: (a) stratification of the pillar (b) stratification of the roof; (c) mineral vein filled by crystalline gypsum; (d) mineral vein filled by ahydrite; (e) flat and inclined layers filled with clay-carbon minerals; (f) stylolite, crossing layers.

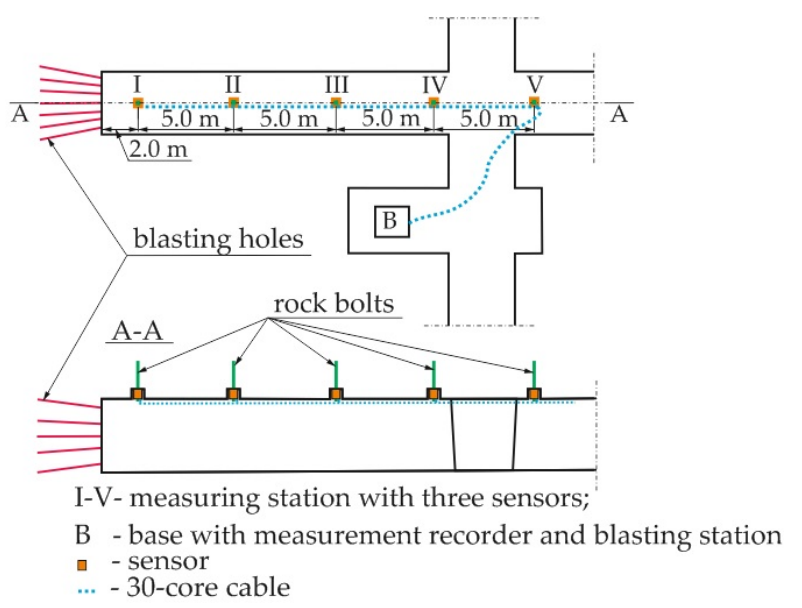

(a)

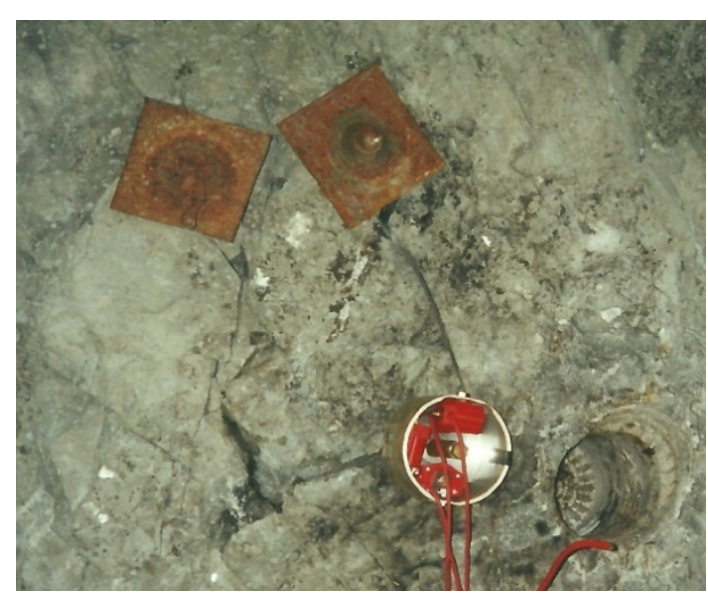

(b)

Figure 4. Test stand in the underground copper ore mine: (a) arrangement of measuring sensors; (b) a general view of the sensor installed in the roof of the room. 


\subsection{Model of Rock Bolt Support under Influence of Geomechanical Seismic Events}

A tremor or rock burst can be treated as an axial impact of the contracted weight on the bolt rod, which on one side is terminated with a bearing plate, while on the other hand it is firmly and rigidly fixed in the bottom of the bolt hole. Assuming that delamination occurred in the stratified roof, which consequently led to the appearance of a fissure (Figure 5) and apart from the associated longitudinal vibrations of the bolt rod and its mass, it can be supposed that the bolt rod supports a set of several rock layers with a total mass of $\mathrm{m}_{1}$, in which are hit with some kinetic energy by the higher layers with higher total mass $m_{2}$. In addition, assuming that the collision of masses $m_{1}$ and $m_{2}$ is plastic, then the kinetic energy of the system after the collision can be expressed according to the following formula:

$$
\mathrm{E}_{\mathrm{k}}=\frac{\left(\mathrm{m}_{1}+\mathrm{m}_{2}\right) \cdot \mathrm{V}_{\mathrm{c}}^{2}}{2}
$$

where:

$\mathrm{V}_{\mathrm{c}}$-velocity of sum of masses $\mathrm{m}_{1}$ and $\mathrm{m}_{2}$ after collision, determined according to the relationship:

$$
\mathrm{V}_{\mathrm{c}}=\frac{\mathrm{m}_{2}}{\mathrm{~m}_{1}+\mathrm{m}_{2}} \cdot \mathrm{V}_{1}
$$

where:

$\mathrm{V}_{1}$-mass velocity $\mathrm{m}_{2}$, which can be expressed according to the following formula:

$$
\mathrm{V}_{1}=\sqrt{2 \cdot \mathrm{g} \cdot \mathrm{h}}
$$

where:

g一 gravitational acceleration $/ \mathrm{m} / \mathrm{s}^{2}$,

$\mathrm{h}$-height of mass drop, $\mathrm{m}_{2} / \mathrm{m}$.

Then, substituting Formulas (2) and (3) for Formula (1), we get the formula for kinetic energy:

$$
E_{k}=\frac{m_{2}^{2} \cdot g \cdot h}{m_{1}+m_{2}}
$$

The change in the kinetic energy of the roof layers is accompanied by a change in the potential energy of these layers, equal in value but with the opposite sign, so that the sum of these changes is equal to zero. Each change in the kinetic energy $E_{k}$ of the roof layers is balanced by a change in the potential energy $E_{p}$, so that their sum remains constant at all times. For moving roof rock layers, potential energy is expressed by the following formula:

$$
E_{p}=m_{1} \cdot g \cdot d+m_{2} \cdot g \cdot d=\left(m_{1}+m_{2}\right) \cdot g \cdot d
$$

The total impact energy $\left(E_{\mathrm{i}}\right)$ acting on the bolt support is the sum of the kinetic and potential energy:

$$
E_{i}=E_{k}+E_{p}=\frac{m_{2}^{2} \cdot g \cdot h}{m_{1}+m_{2}}+\left(m_{1}+m_{2}\right) \cdot g \cdot d
$$

where:

$\mathrm{E}_{\mathrm{i}}$-impact energy/J,

$\mathrm{d}$-bolt displacement (extension from the hole + strain of bolt rod + flattening of bearing plates) $/ \mathrm{m}$,

$\mathrm{m}_{1}$ - total mass of layers below the fissure $/ \mathrm{kg}$,

$\mathrm{m}_{2}$ - total mass of layers above the fissure $/ \mathrm{kg}$. 


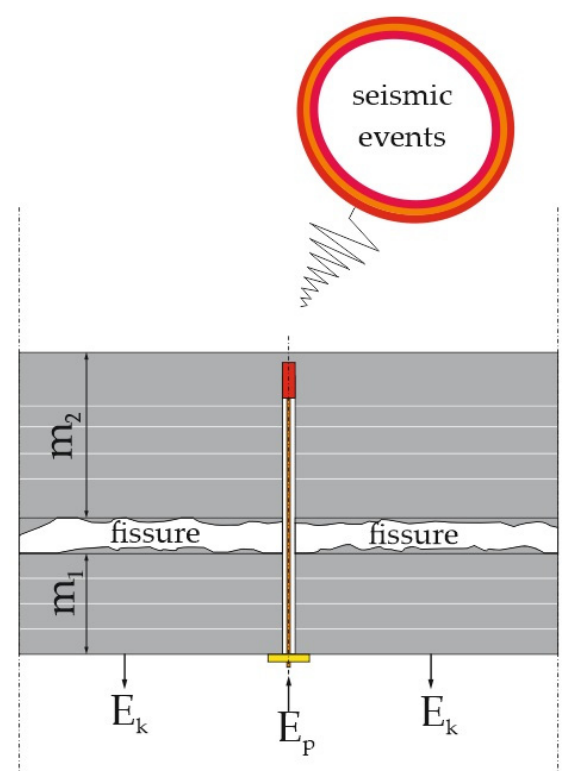

Figure 5. Impact load model for rock bolt support due to geomechanical seismic events.

The load model of the mechanical rock bolt support is characteristic for the stratified rock mass occurring in the underground LGOM mines. Fissures and delaminations occur between the expansion head and the bearing plate. The confirmation of this phenomenon is the increase of the bolt load, in particular for installing segmentally (Figure 6a). As a result of the moving of the operating front in the room and pillar method, the pillars are crushed and creep, which is accompanied by an increase in the convergence of the excavation (Figure 6b). In situ tests carried out by Skrzypkowski [37] in the Polkowice-Sieroszowice mine, owned by KGHM Polska Miedź SA, which exploits the orebody with a room and pillar with roof sag, indicates that the average increase of rock bolt load and vertical convergence of room are: $0.53 \mathrm{kN} /$ day to $0.63 \mathrm{kN} /$ day, respectively and $4.9 \mathrm{~mm} /$ day to $8.4 \mathrm{~mm} /$ day, respectively [37].

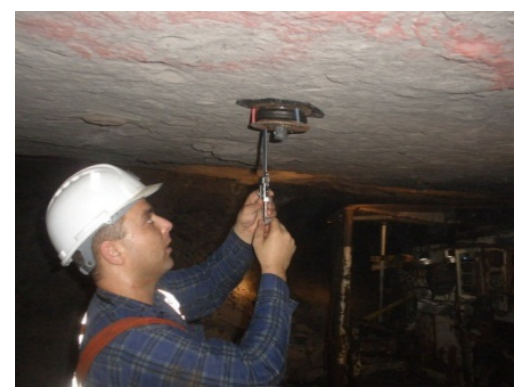

(a)

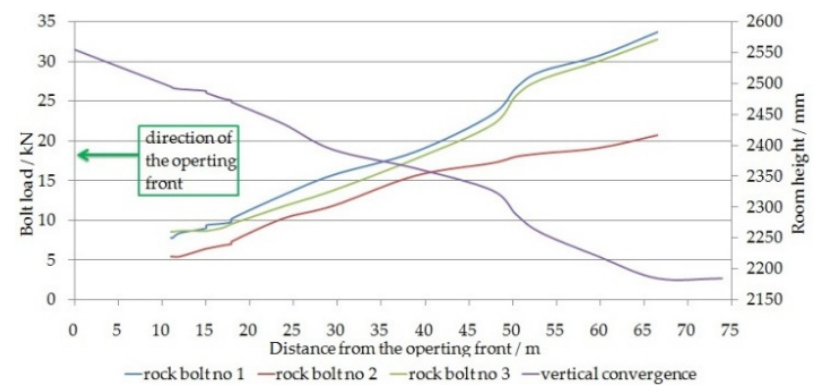

(b)

Figure 6. In situ tests of rock bolt support in a stratified rock mass: (a) indirect bolt load measurement; (b) increase of bolt load and room convergence in reference to the distance from the operating front.

In the proposed mathematical model, the greatest uncertainty is the height of drop $h$, in which the mass $m_{2}$ hits the mass $m_{1}$. In case of stratification appearing above the bolted zone, the rock bolt support loses its functionality and most often the roof rocks collapse. For this reason, monitoring of the rock mass and the bolt support is necessary [38-40]. Some uncertainties are also related to the strain of the bolt rod, embedded on the resin cartridges along the entire length, where the unbound section is very short, usually the thread part of the bolt rod. In this case, the mechanical bolt has an advantage due to the longer deformable section of the bolt rod. 


\section{Laboratory Tensile Tests of Mechanical Bolt Support}

\subsection{Technical Characteristics of the Mechanical Sleeve Bolt Support}

Laboratory tensile tests of mechanical bolt support were carried out at the Department of Mining Engineering and Occupational Safety at the Faculty of Mining and Geoengineering of the AGH University of Science and Technology in Krakow. In the tests, bolts with a mechanical head $25.4 \mathrm{~mm}$ in diameter were used. The mechanical head consisted of a conical nut and a rounded sleeve (Figure 7a). The bolt support consisted of a smooth $1.6 \mathrm{~m}$-long rod made of AP-600 steel grade. It is a steel with a yield strength $\mathrm{R}_{\mathrm{e}}$ equals to at least $400 \mathrm{MPa}$, a tensile strength of at least $600 \mathrm{MPa}$ and a minimal percentage elongation of $\mathrm{A}_{5}$ equals to $19 \%$ [41,42]. The diameter of the smooth bolt rod was $18.3 \mathrm{~mm}$. On one side, the bolt rod was terminated with an M18 thread $89 \mathrm{~mm}$ long and $17.3 \mathrm{~mm}$ in diameter, preceded by two steel washers $22.3 \mathrm{~mm}$ in diameter and $2.5 \mathrm{~mm}$ thick, on which the sleeve mechanical head was screwed (Figure $7 \mathrm{~b}$ ). The mechanical head consisted of a round sleeve with a diameter of $24.8 \mathrm{~mm}$ and a total length of $58.85 \mathrm{~mm}$. The round sleeve up to $51.65 \mathrm{~mm}$ long had four circumferential slots $2.3 \mathrm{~mm}$ wide, which served as guides for the conical nut. The second essential element of the mechanical head was a conical nut $35 \mathrm{~mm}$ high, $22.7 \mathrm{~mm}$ and $25.8 \mathrm{~mm}$ in diameter for its upper and lower part, respectively. On the other hand, the bolt rod had swelling ended with an M30 hexagonal profile. The sleeve mechanical head was installed in a rock core (dolomite) taken from the roof of the room excavation. A rock core with a diameter of $90 \mathrm{~mm}$ and a length of $270 \mathrm{~mm}$ was bonded into a steel cylinder with a diameter of $102 \mathrm{~mm}$ and a sheet thickness of $6 \mathrm{~mm}$. Holes in the cores were made using a hand-held rotary drill equipped with a core drill bit. The diameter of the holes was $25.50 \mathrm{~mm}$ (Figure 8). The bolt rod cooperated with a steel, square, flat profiled bearing plate with a sheet thickness of $6 \mathrm{~mm}$ and a side length of $150 \mathrm{~mm}$ (Figure 9a or Figure 10a). In order to make the bolt support more yielding, in the tests a round and dome bearing plate with a sheet thickness of $6 \mathrm{~mm}$, a diameter of $150 \mathrm{~mm}$ and a height of $25 \mathrm{~mm}$ (Figure $9 \mathrm{~b}$ or Figure 10b) was used. In the laboratory tests, the system of cooperation of the bolt rod with one, two (Figure 7c or Figure 8c), four (Figure 9d or Figure 10d) and six (Figure 9e or Figure 10e) dome bearing plates were tested. The height of the bearing plate system was $25 \mathrm{~mm}, 50, \mathrm{~mm}, 100 \mathrm{~mm}$ and $150 \mathrm{~mm}$, for: one, two, four and six dome bearing plates (steel grade St3SAL), respectively.

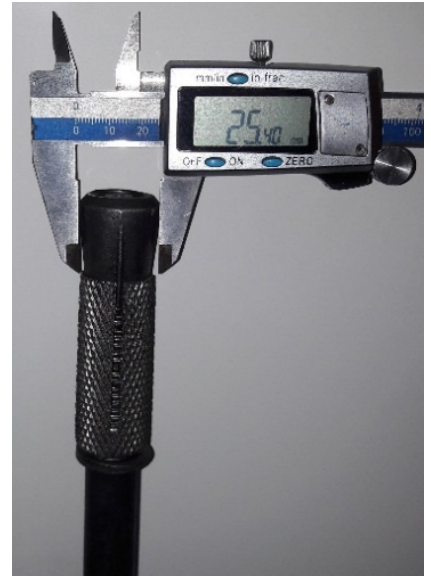

(a)

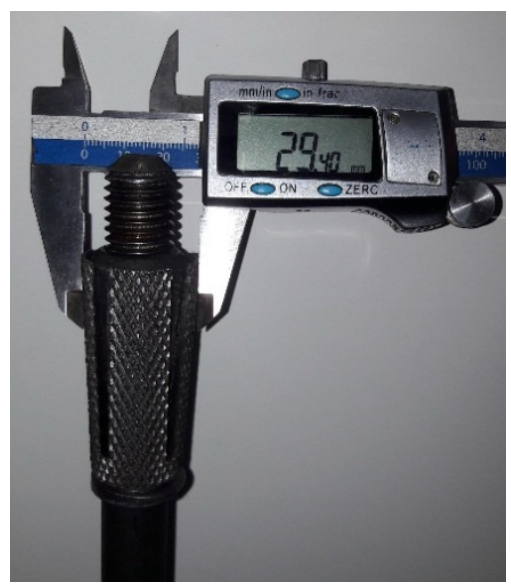

(b)

Figure 7. Mechanical sleeve head screwed on the bolt rod: (a) before spreading; (b) at maximal spreading. 


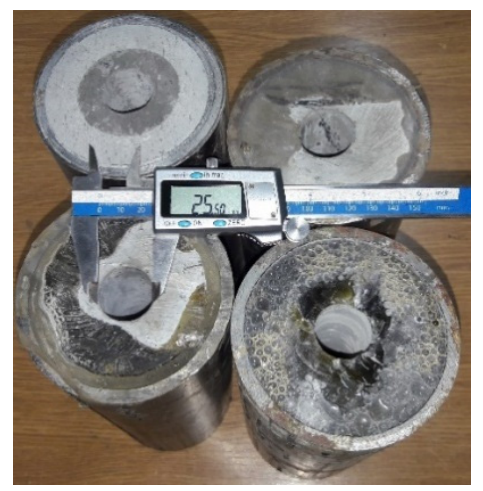

Figure 8. Rock cores (dolomites) installed to steel cylinders.

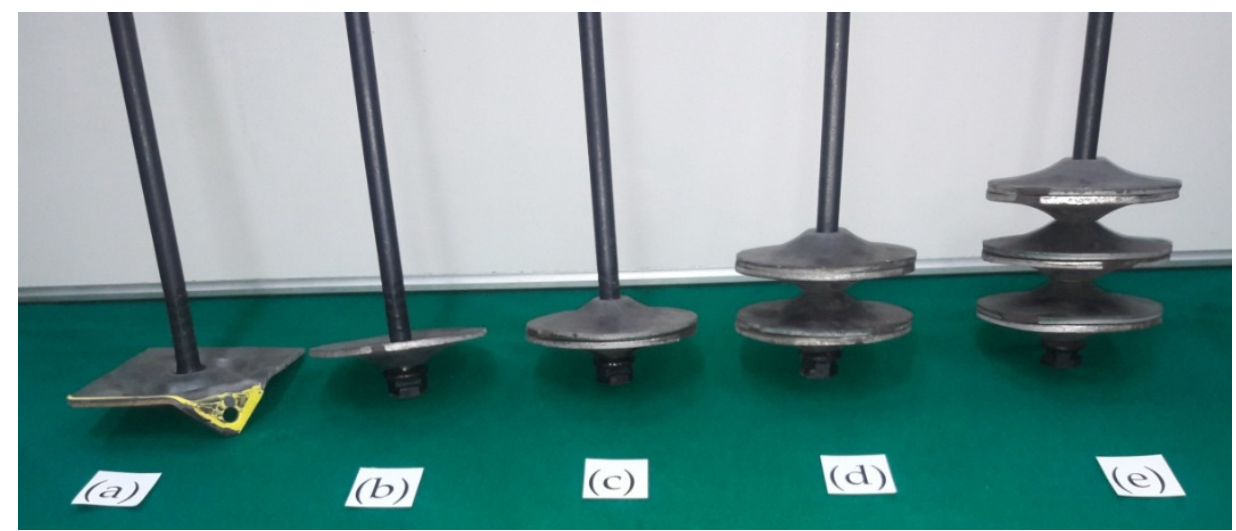

Figure 9. The bearing plates configuration used in the laboratory tests: (a) square shaped flat; (b) round profiled dome; (c) two round profiled domes; (d) four round profiled domes; (e) six round profiled domes.

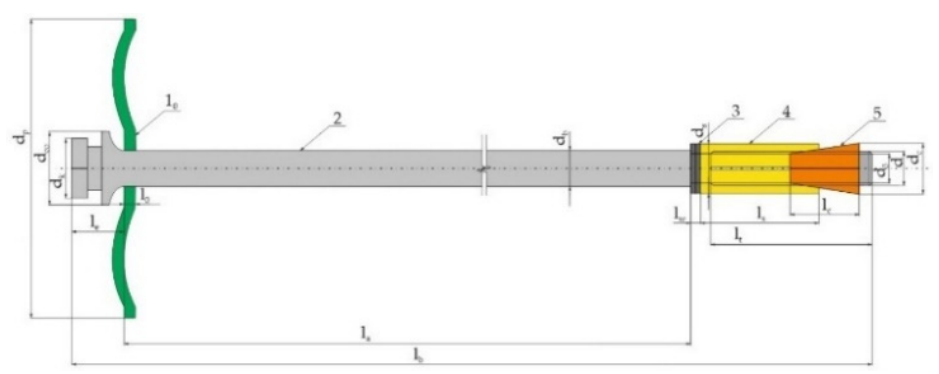

(a)

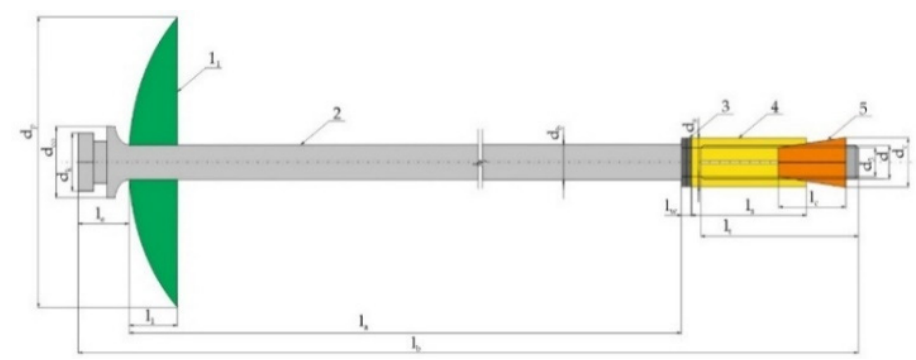

(b)

Figure 10. Cont. 


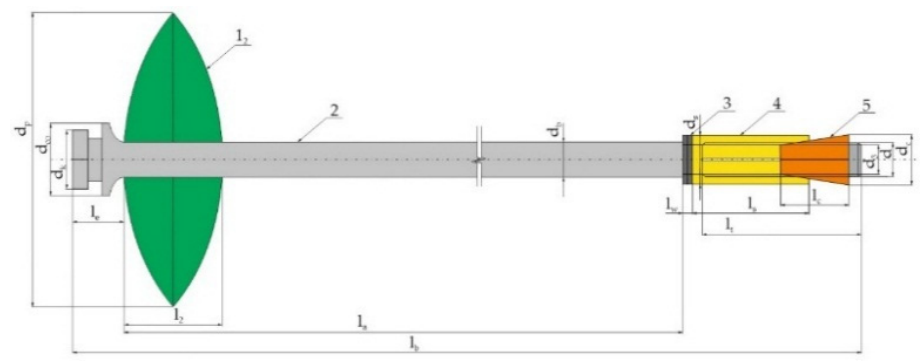

(c)

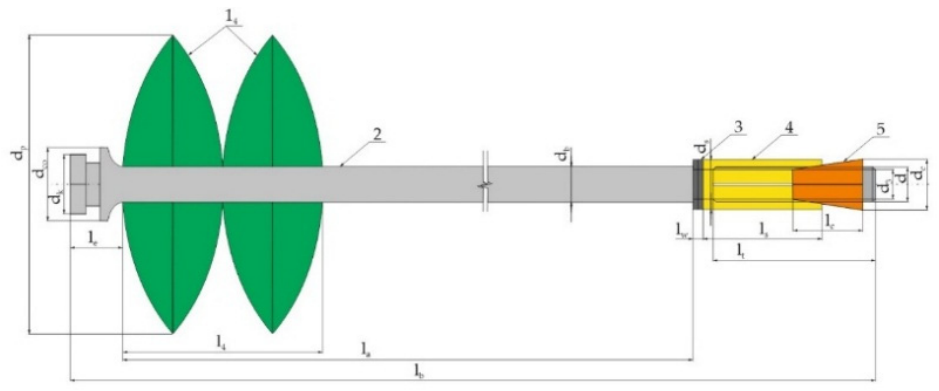

(d)

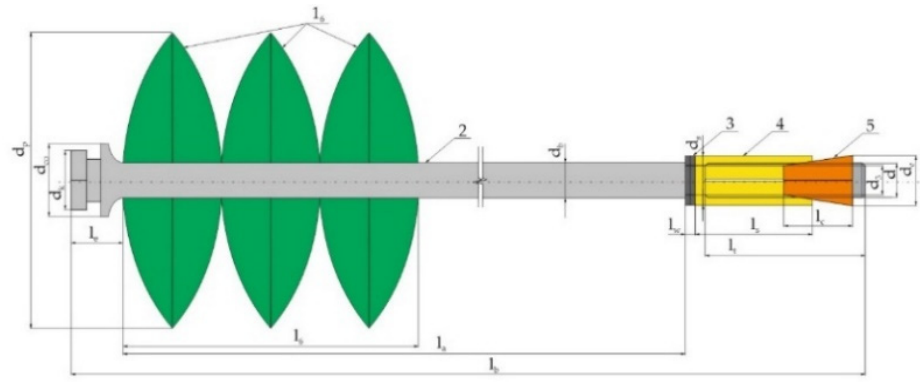

(e)

Figure 10. Configuration of the connection of the bolt rod with bearing plates: (a) square shaped flat; (b) round profiled dome; (c) two round profiled domes; (d) four round profiled domes; (e) six round profiled domes; $1_{0}$-square bearing plate, sheet metal thickness $6 \mathrm{~mm} ; 1_{1}$-round, profiled dome bearing plate, $25 \mathrm{~mm}$ thick; $1_{2}$-two round, profiled dome bearing plates with a total thickness of $50 \mathrm{~mm}$; $1_{4}$-four round profiled dome bearing plates with a total thickness of $100 \mathrm{~mm} ; 1_{6}$-six profiled dome bearing plates with a total thickness of $150 \mathrm{~mm}$; 2-smooth bolt rod; 3-two rounded bearing plates, constituting the limitation of the mechanical sleeve; 4 -mechanical sleeve; 5 -conical spreader; $\mathrm{d}_{\mathrm{p}}$-bearing plate diameter $(150 \mathrm{~mm}) ; \mathrm{d}_{\mathrm{co}}$-diameter of the swollen bolt rod end $(36 \mathrm{~mm}) ; \mathrm{d}_{\mathrm{k}}$-hexagonal bolt rod end $(30 \mathrm{~mm}) ; \mathrm{d}_{\mathrm{b}}$-rod diameter $(18.3 \mathrm{~mm}) ; \mathrm{d}_{\mathrm{s}}$-diameter of a rounded washers $(25 \mathrm{~mm}) ; \mathrm{d}_{3}$-thread core diameter $(14.93 \mathrm{~mm})$; d-thread diameter $(17.3 \mathrm{~mm})$; $\mathrm{d}_{\mathrm{c}}$-diameter of the conical spreader $(25.4 \mathrm{~mm})$; $l_{\mathrm{e}}$-the length of the bolt rod end with a variable diameter, larger than the diameter of the bolt rod $(33 \mathrm{~mm}) ; 1_{0}$-height of the square bearing plate $(6 \mathrm{~mm}) ; 1_{1}$-height of the round, profiled dome bearing plate $(25 \mathrm{~mm}) ; 1_{2}$-height of two round, profiled dome bearing plates $(50 \mathrm{~mm}) ; 1_{4}$-height of four profiled dome bearing plates $(100 \mathrm{~mm}) ; 1_{6}$-height of six profiled dome bearing plates $(150 \mathrm{~mm}) ; \mathrm{l}_{\mathrm{a}}$-rod length with a diameter $18.3 \mathrm{~mm}(1478 \mathrm{~mm}) ; 1_{\mathrm{b}}$-total length of the bolt rod $(1.6 \mathrm{~m}) ; 1_{\mathrm{w}}$-length of the smooth part of the bolt rod $(5 \mathrm{~mm}) ; 1_{\mathrm{t}}$-thread length $(84 \mathrm{~mm}) ; 1_{\mathrm{s}}$-sleeve length $(58.85 \mathrm{~mm}) ; 1_{\mathrm{c}}-$ length of a conical spreader $(35 \mathrm{~mm})$.

\subsection{Load-Dispalacement Characteristics of Yielding Mechaniacal Bolt Support}

The rock bolt with a sleeve mechanical head was subjected to tensile tests on a testing machine in the bolting laboratory, which was specially designed for testing rock bolt support in a geometric 
scale 1:1 [43,44]. In the tests, a bolt hole diameter of $25.5 \mathrm{~mm}$ was used; the choice of this diameter corresponded to the technology of bolting in industrial conditions. After manual insertion of the bolt into the hole (Figure 11a), the mechanical head was expanded with a torque wrench, allowing for pre-tensioning in the range from $20 \mathrm{kN}$ to $25 \mathrm{kN}$ (Figure 11b). The tightening torque was $250 \mathrm{Nm}$. For this installing configuration, five bolts equipped with one, two, four and six dome bearing plates and one flat bearing plate were tested. Bolt support were tested under fast changing loads. The test duration was less than $2 \mathrm{~s}$. To measure the load, four strain gauges, which were mounted on the extending hydraulic disk were used. Measurement of displacement using an incremental line encoder, whose cable was stretched between the stand base and the hydraulic disc, was carried out. The sensors were connected to a universal measuring amplifier type QUANTUM MX840A, which in turn was connected to a portable computer. The measurement results were continuously recorded by using Catman-Easy software. The test results are presented in Figure 12a-e and in a Table 1.

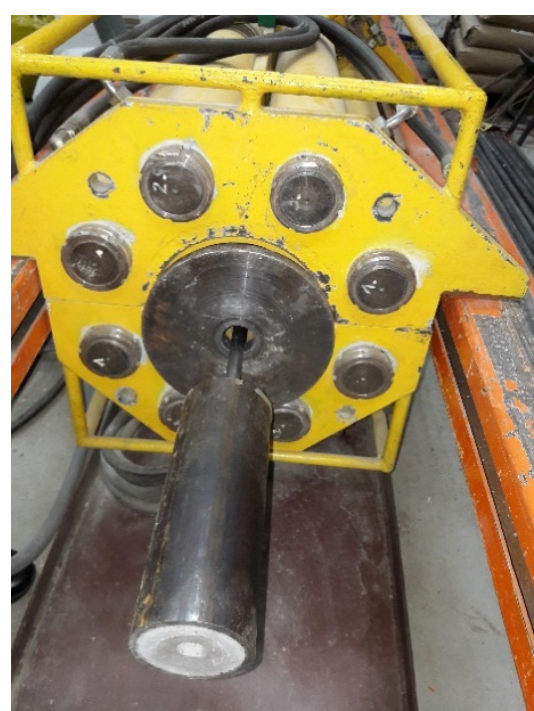

(a)

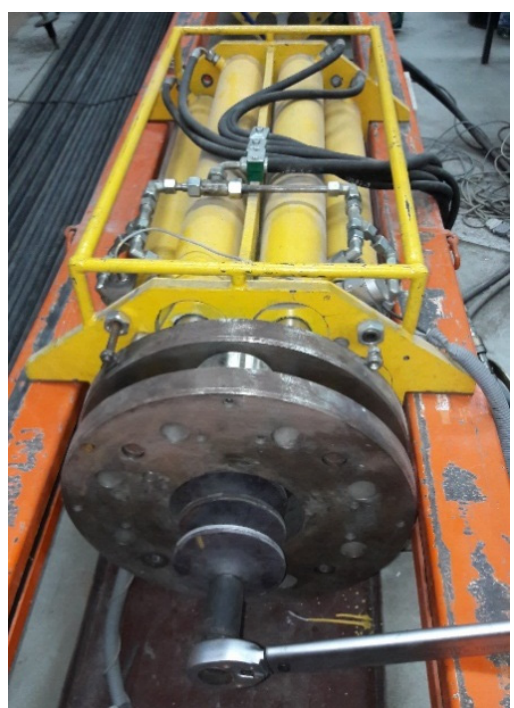

(b)

Figure 11. Installation of the rock bolt support on the laboratory station: (a) arrangement of bolt rod with a mechanical head into rock core (without extending the cylinders); (b) pre-tension (at full spread of the bolt).

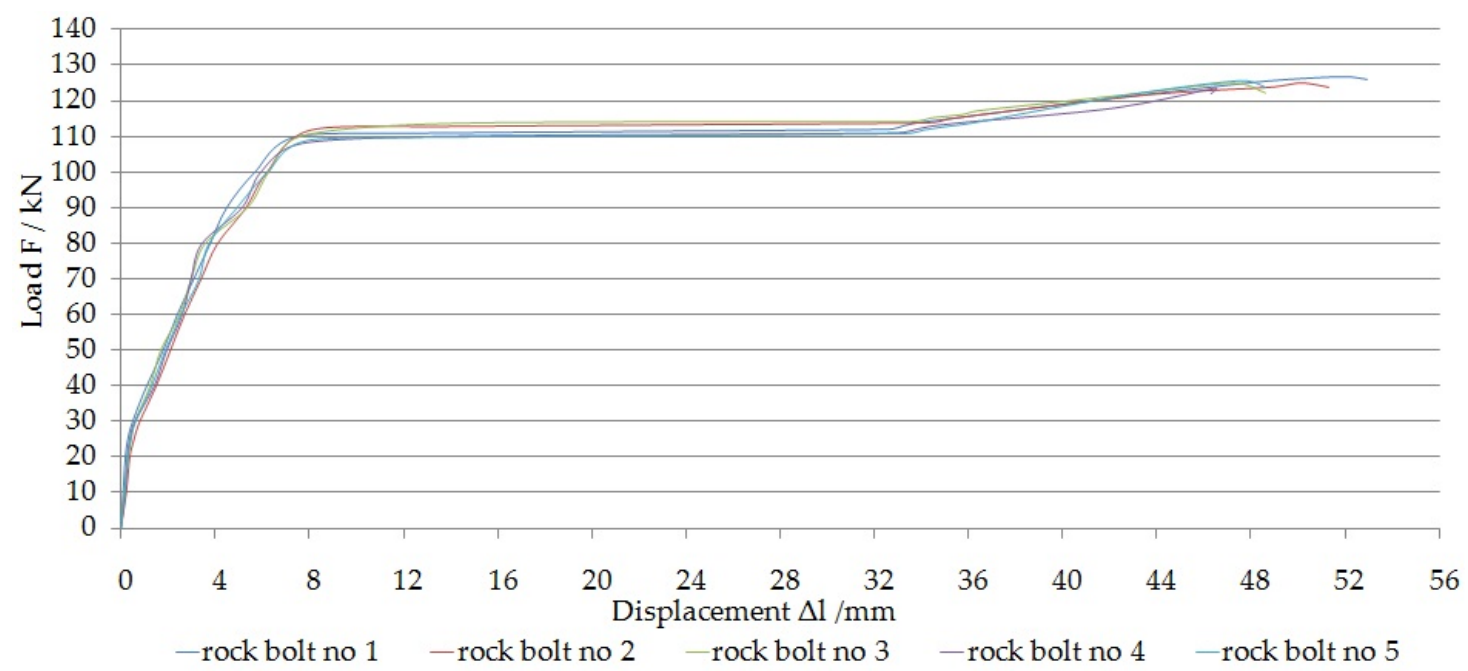

(a)

Figure 12. Cont. 


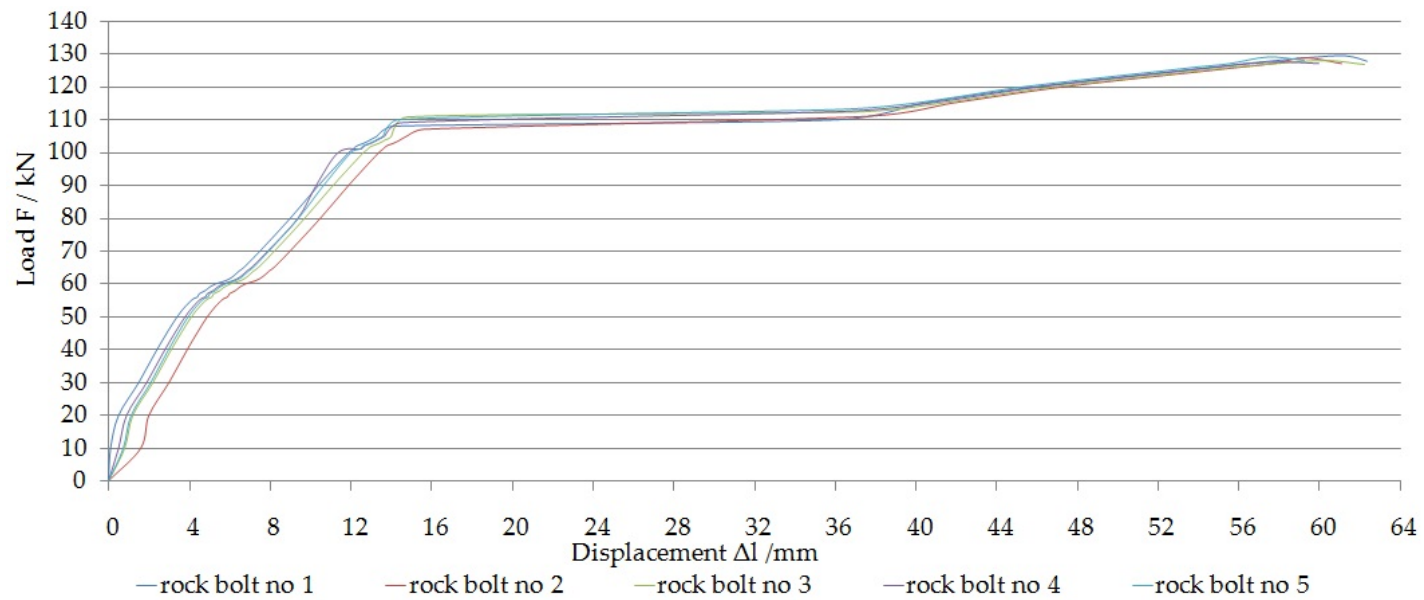

(b)

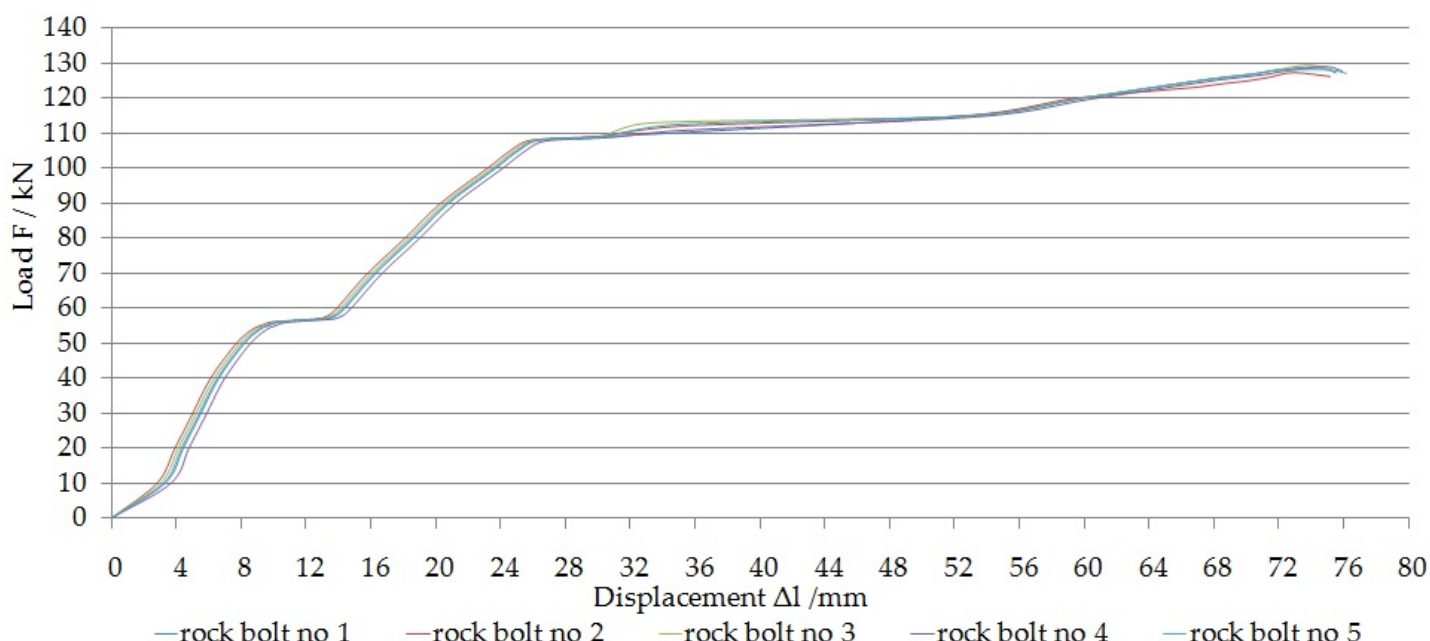

(c)

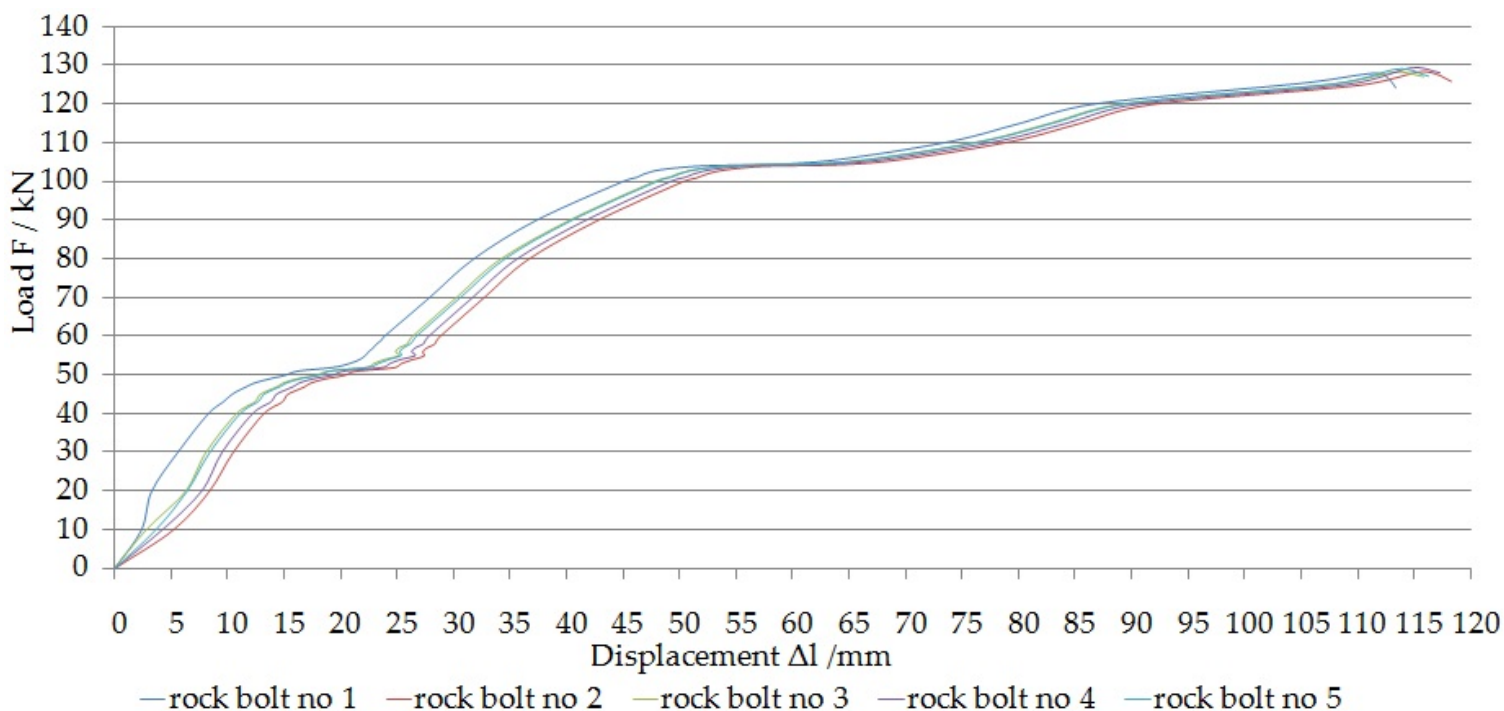

(d)

Figure 12. Cont. 


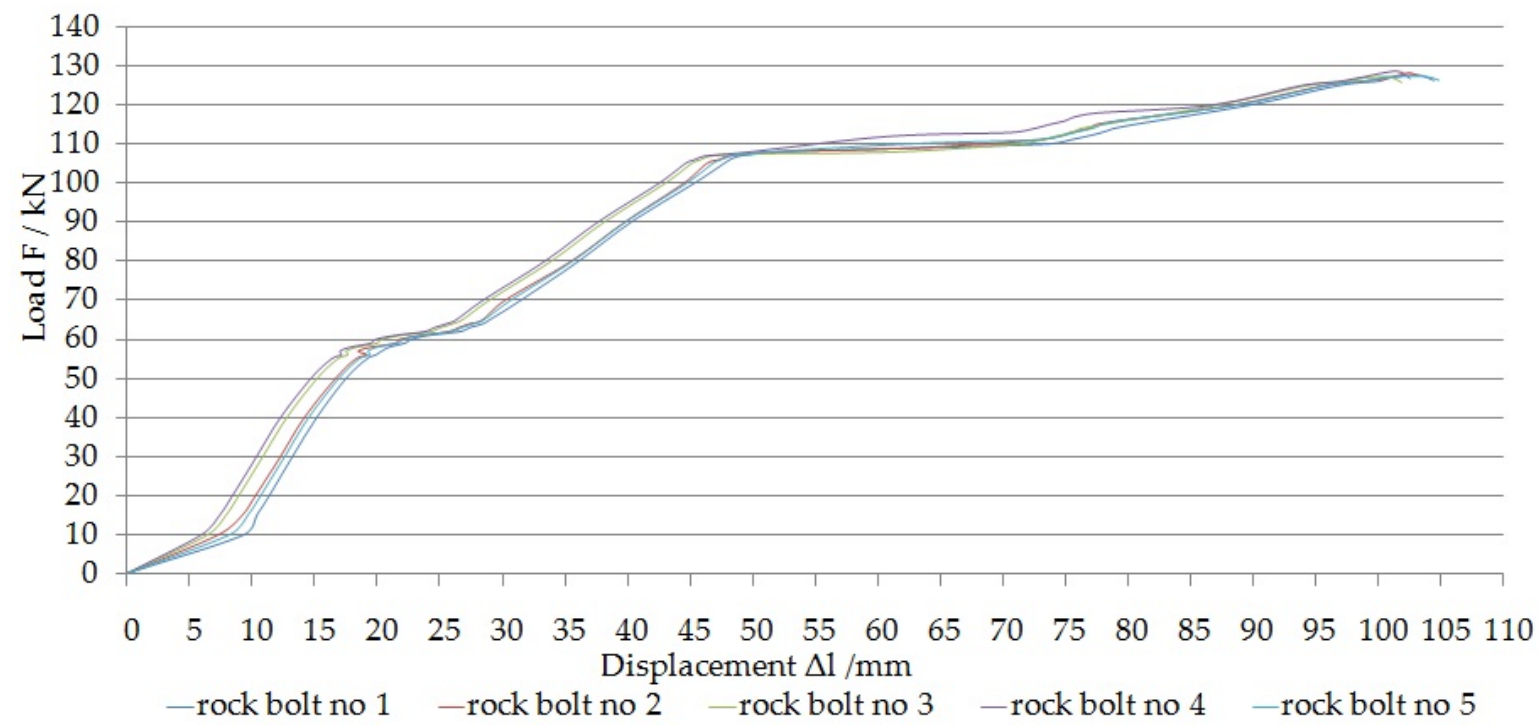

(e)

Figure 12. Load-displacement characteristics of a 1.6 long rock bolt support equipped with the sleeve mechanical head with bearing plate: (a) flat; (b) dome; (c) two domes; (d) four domes; (e) six domes.

Table 1. Average displacement and load values of the $1.6 \mathrm{~m}$-long rock bolt support equipped with the sleeve mechanical head.

\begin{tabular}{|c|c|c|c|c|}
\hline $\begin{array}{l}\text { Bearing Plate } \\
\text { Shape }\end{array}$ & $\begin{array}{c}\text { Number of } \\
\text { Bearing Plates }\end{array}$ & $\begin{array}{l}\text { Average Bolt } \\
\text { Capacity (F/Kn) }\end{array}$ & $\begin{array}{c}\text { Average } \\
\text { Displacement } \\
(\Delta \mathrm{l} / \mathrm{mm})\end{array}$ & $\begin{array}{l}\text { Deformation of } \\
\text { Bearing Plates } \\
\text { (mm) }\end{array}$ \\
\hline flat & 1 & 125.22 & 48.68 & 1 \\
\hline \multirow{4}{*}{ dome } & 1 & 127.28 & 59.28 & 8.6 \\
\hline & 2 & 128.60 & 74.22 & 17.36 \\
\hline & 4 & 128.85 & 113.78 & 45.25 \\
\hline & 6 & 127.77 & 102.33 & 43.55 \\
\hline
\end{tabular}

In all cases, the rod material was broken in the thread.

\subsection{Work Done by Bolt Support $\left(W_{b}\right)$}

In order for the bolt support not to be damaged during its impact load, the work done by the bolt support $\left(\mathrm{W}_{\mathrm{b}}\right)$ must be greater than the total impact energy $\left(\mathrm{E}_{\mathrm{i}}\right)$. In the article, the work done by the yielding bolt support was determined on the basis of calculating the area under the curve from load-displacement characteristics obtained from laboratory tests $[45,46]$ of tensile bolts with a length of $1.6 \mathrm{~m}$ (Figure 13). 


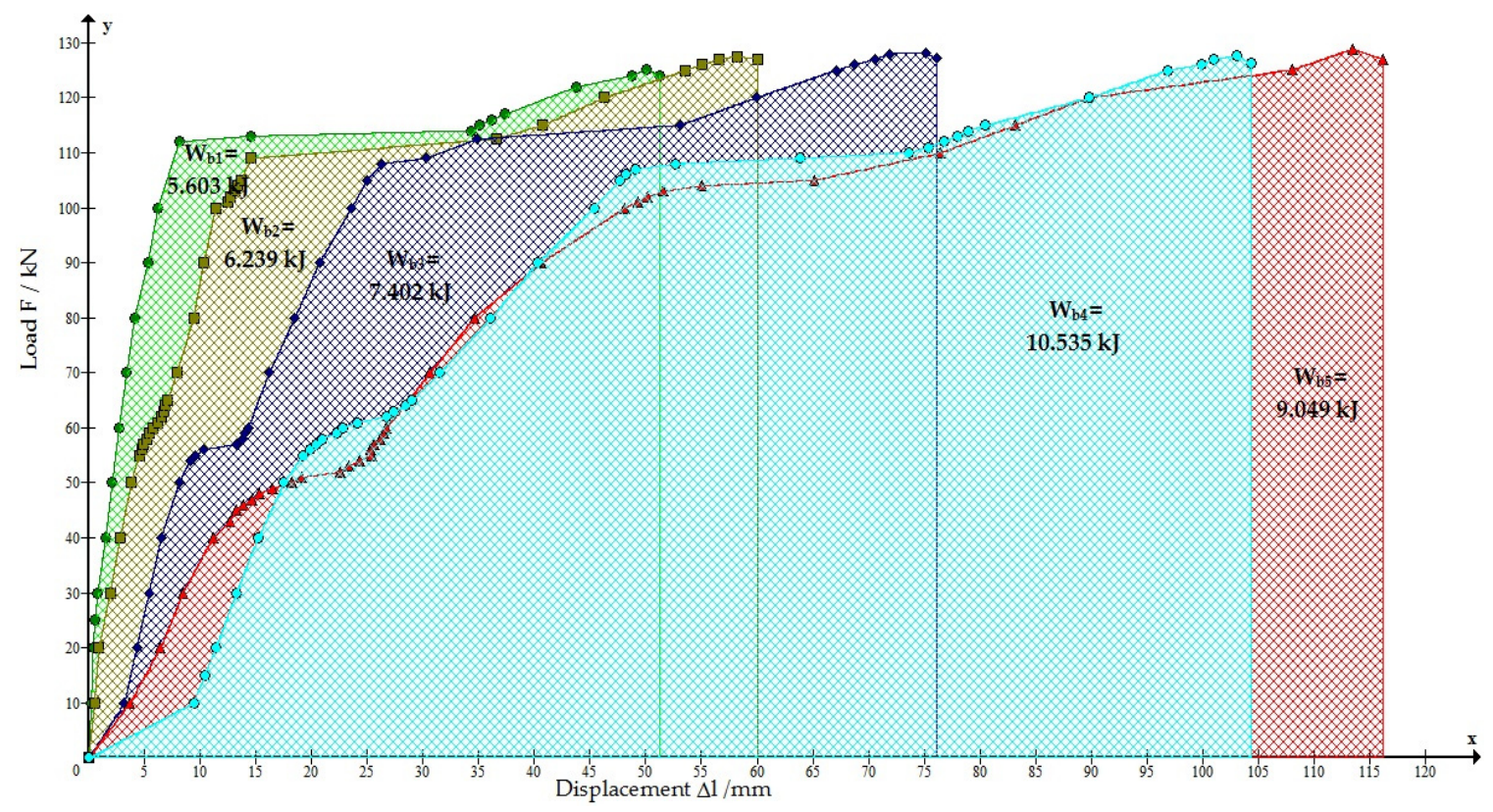

Figure 13. Work done by a $1.6 \mathrm{~m}$-long rock bolt support equipped with the sleeve mechanical head with bearing plate: $\mathrm{W}_{\mathrm{b} 1}$-flat; $\mathrm{W}_{\mathrm{b} 2}$-dome; $\mathrm{W}_{\mathrm{b} 3}$-two domes; $\mathrm{W}_{\mathrm{b} 4}$-four domes; $\mathrm{W}_{\mathrm{b} 6}$-six domes.

\section{Numerical Modeling of the Influence of Room Width on the Total Displacements and Range of Rock Destruction in the Stratified Roof}

Numerical model tests were performed in the Phase2D program, which is based on the finite element method. In the numerical program five variants of the width of rooms and pillars, which were located at a depth of $1000 \mathrm{~m}$ below the ground surface, were designed. The widths of rooms and pillars were: $7 \mathrm{~m} \times 7 \mathrm{~m} ; 8 \mathrm{~m} \times 6 \mathrm{~m}, 9 \mathrm{~m} \times 5 \mathrm{~m} ; 10 \mathrm{~m} \times 4 \mathrm{~m} ; 11 \mathrm{~m} \times 3 \mathrm{~m}$, respectively (Figure 14). The basic purpose of numerical modeling was to determine the maximal range of the rock destruction zone and total displacements in the expansion phase of room excavations. In the room and pillar method with roof sag, the copper ore deposit is selected with rooms up to $7 \mathrm{~m}$ wide, driven to the full thickness of the bed up to $4.5 \mathrm{~m}$, separating technological pillars with a basic geometry of $7 \mathrm{~m}$ width and $8 \mathrm{~m}$ length. As the exploitation front progresses, the technological pillars located on the liquidation line are cut apart, and the pillars created in this way are taken to residual dimensions and left in the post-exploitation space, where they act as supports supporting the curvature of the sag roof layers. Loading capacity of residual pillars is selected so as to secure the stability of the roof in the area of the liquidated field, while allowing its gentle sag. The minimal area of the remaining residual pillars in contact with the roof should be at least $12 \mathrm{~m}^{2}$. In the modeling, $1.6 \mathrm{~m}$-long bolts with a spacing of $1 \mathrm{~m} \times 1 \mathrm{~m}$ were adopted. The bolts were installed in a stratified roof. The thickness of a single layer in the bolted zone was $0.20 \mathrm{~m}$. The choice of bolting scheme reflected industrial conditions. Strength, deformation and structural parameters of the rock mass are shown in Figure 14.

The numerical elastic model of the exploitation room was created in the Phase $^{2}$ program, which is based on the finite element method. For a strong rock mass it is possible to use such an elastic model [47]. Prediction of the damage area and total displacement is a vital part of the underground excavation design process. These calculations can be used to identify the areas in which the strength of the rock is exceeded and they can be used to design the support system for these failure areas [48]. In the calculations, the Hoek-Brown strength criterion [49] was used, which determines the empirical relationship between principal stresses and rock compressive strength as well as $m b, s$ and $a$, parameters (characterizing rock mass quality), which were selected using the Rocklab program [49]. The range of the rock damage area in the roof of expanded and the nearest room in the numerical model used the strength factor (SF) expressing the relationship between rock strength and the equivalent stress at 
a given point. If the SF value is lower than 1, the equivalent stress exceeds the strength of the rock mass at the point, and material failure may occur (plastic analysis). Assuming that the system is elastic, no material failure occurs. The Phase ${ }^{2}$ software calculates the value of each mesh node based on a two-dimension finite element method, having the ability of pseudo dynamic analysis and hence can simulate the effect of tremors on the excavation stability [50]. In numerical modeling, it was assumed that the excavation is dynamically loaded by taking into account the seismic load, which is the product of the seismic coefficient equaling two and the primary stress. The dynamic integration scheme utilized in Phase ${ }^{2}$ is based on the N.M. Newmark [51] family of time-stepping methods which are characterized by the following equations [49]:

$$
\begin{gathered}
v_{\mathrm{i}+1}=v_{\mathrm{i}}+[(1-\beta) \cdot \Delta \mathrm{t}] \cdot a_{\mathrm{i}}+(\beta \cdot \Delta \mathrm{t}) \cdot a_{\mathrm{i}+1} \\
u_{\mathrm{i}+1}=u_{\mathrm{i}}+(\Delta \mathrm{t}) \cdot v_{\mathrm{i}}+\left[\left(\frac{1}{2}-\gamma\right) \cdot(\Delta \mathrm{t})^{2}\right] \cdot a_{\mathrm{i}}+\left[\gamma \cdot(\Delta \mathrm{t})^{2}\right] \cdot a_{\mathrm{i}+1}
\end{gathered}
$$

where $u, v$ and $a$ represent displacement, velocity and acceleration respectively. The $\beta$ and $\gamma$ parameters define how the acceleration over any given time step varies and influence greatly the stability and accuracy of the algorithm. The results of numerical modeling are presented in Figure 15a-e, and in Table 2.

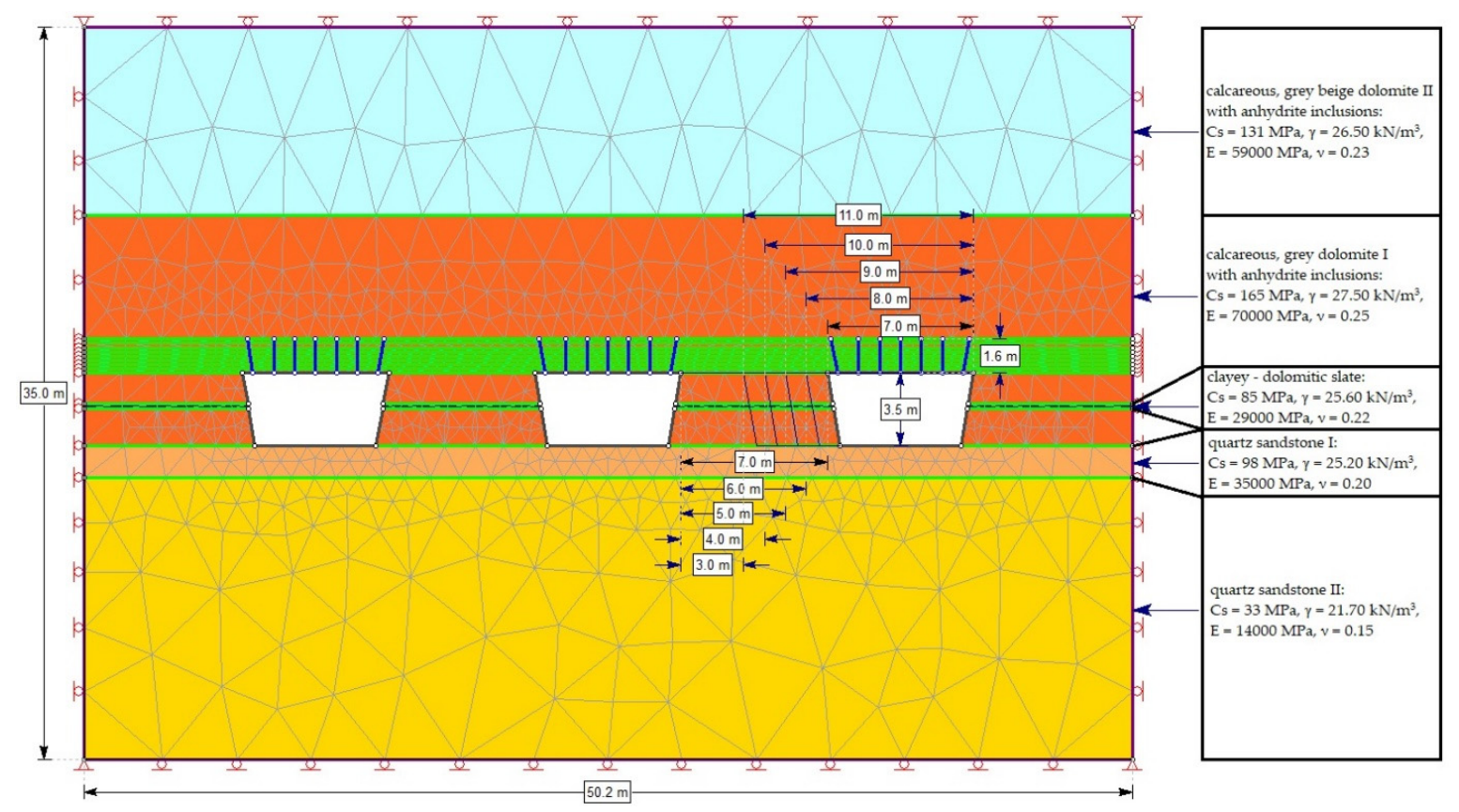

Figure 14. Part of the rock mass model with marked variable room and pillar width: Cs-compressive strength; $\gamma$-bulk density; E-Young's modulus; $v$-Poisson's ratio.

Table 2. Summary of numerical modeling for expanded room.

\begin{tabular}{cccccc}
\hline $\begin{array}{c}\text { Room } \\
\text { Width }(\mathbf{m})\end{array}$ & $\begin{array}{c}\text { Pillar } \\
\text { Width }(\mathbf{m})\end{array}$ & $\begin{array}{c}\text { Range of the Rock } \\
\text { Damage Area in the } \\
\text { Roof of Expanded } \\
\text { Room }(\mathbf{m})\end{array}$ & $\begin{array}{c}\text { Total } \\
\text { Displacement } \\
\text { of Expanded } \\
\text { Room } \mathbf{( m )}\end{array}$ & $\begin{array}{c}\text { Range of the Rock } \\
\text { Damage Area in the } \\
\text { Roof of Adjacent } \\
\text { Room }(\mathbf{m})\end{array}$ & $\begin{array}{c}\text { Total } \\
\text { Displacement in } \\
\text { the Adjacent } \\
\text { Room (m) }\end{array}$ \\
\hline 7 & 7 & 1.168 & 0.256 & 1.100 & 0.240 \\
\hline 8 & 6 & 1.584 & 0.268 & 1.168 & 0.208 \\
\hline 9 & 5 & 1.856 & 0.281 & 1.188 & 0.192 \\
\hline 10 & 4 & 2.056 & 0.288 & 1.192 & 0.176 \\
\hline 11 & 3 & 2.391 & 0.296 & 1.196 & 0.144 \\
\hline
\end{tabular}




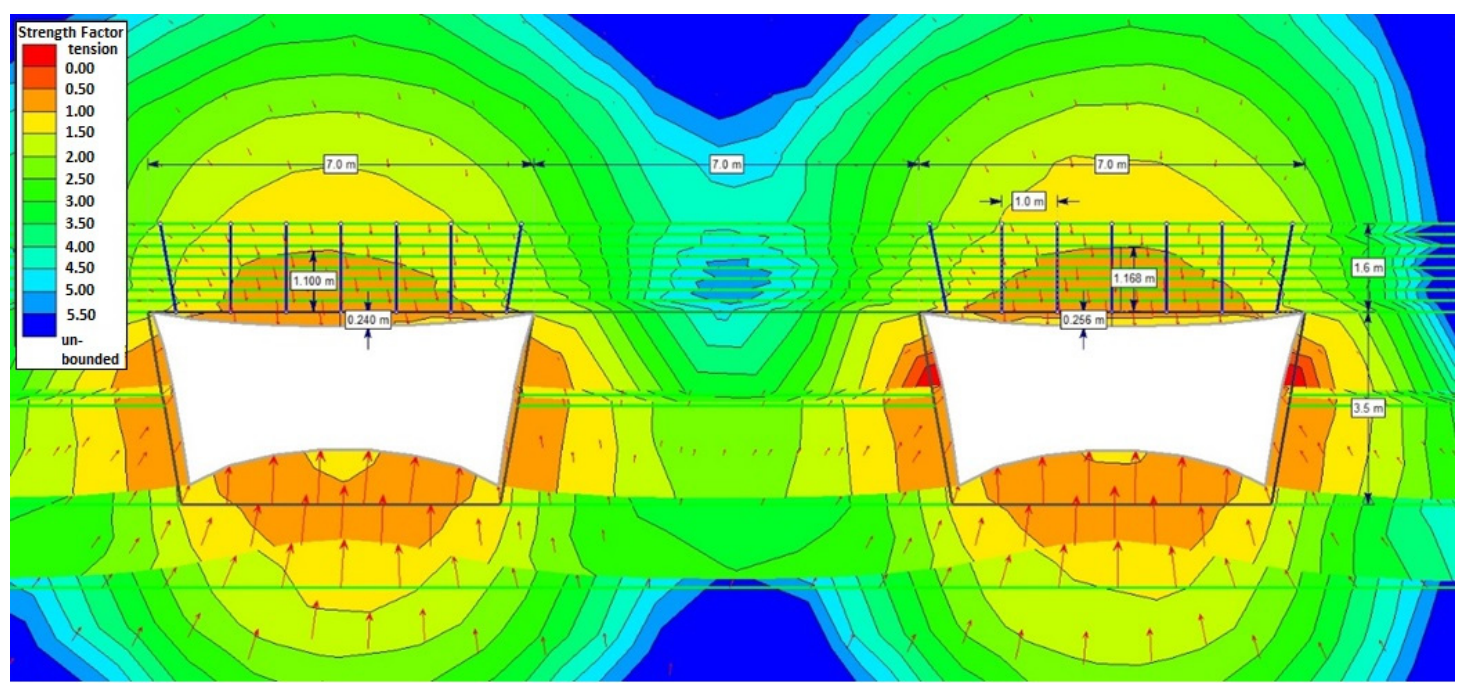

(a)

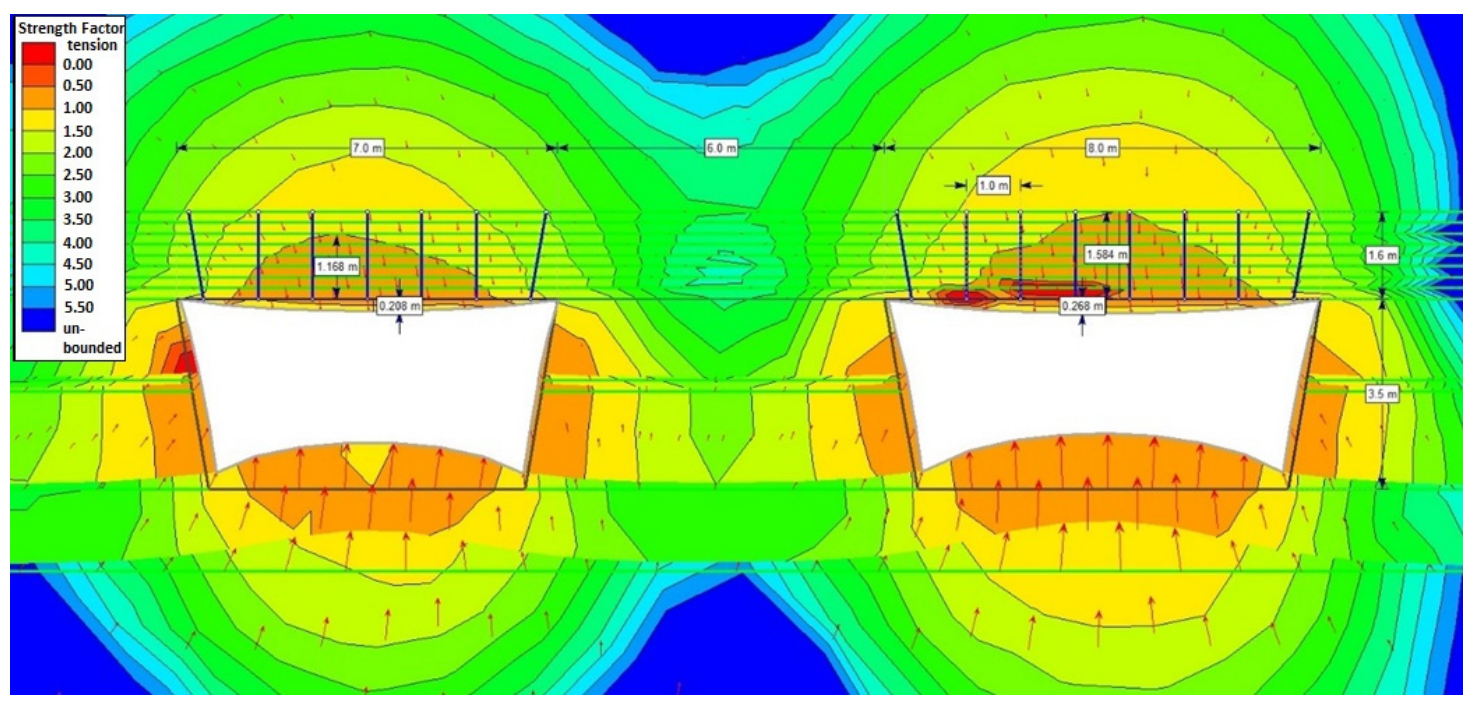

(b)

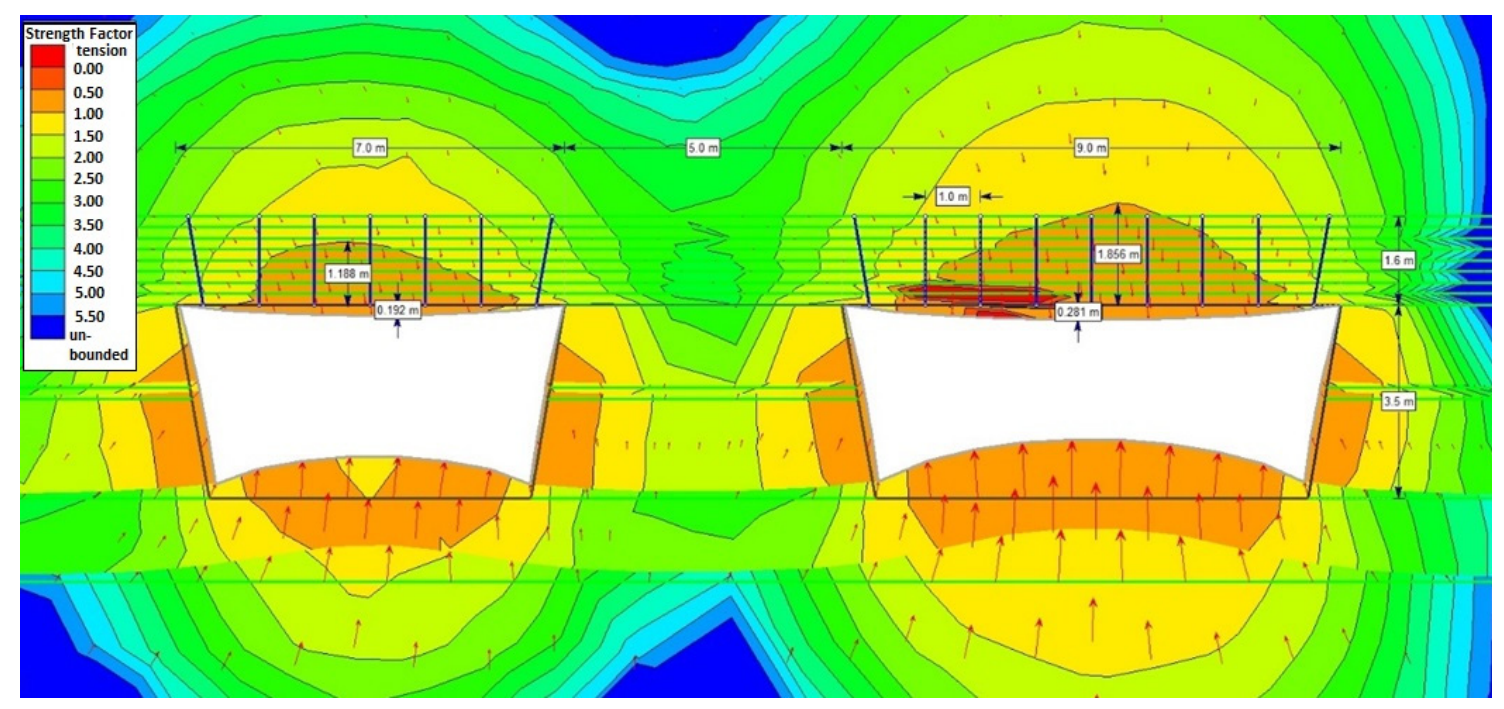

(c)

Figure 15. Cont. 


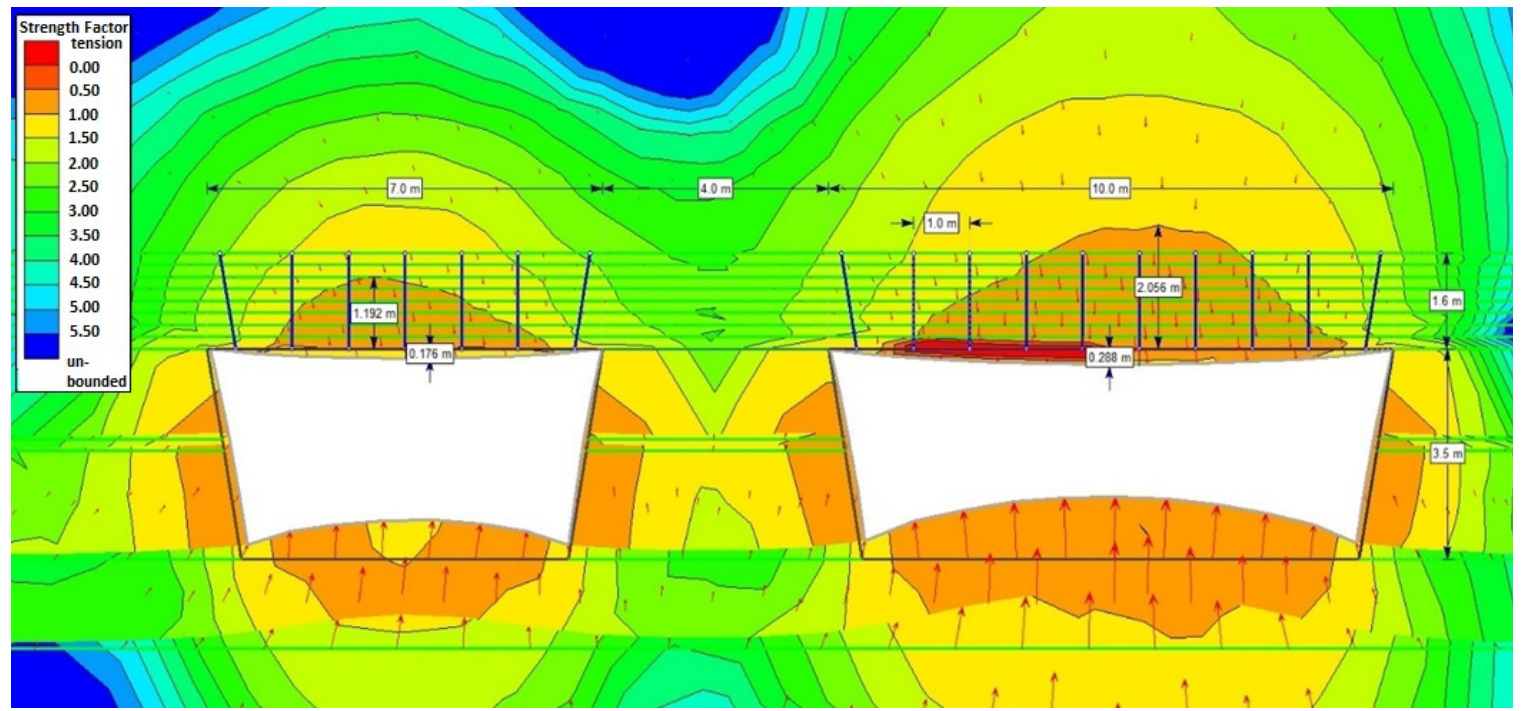

(d)

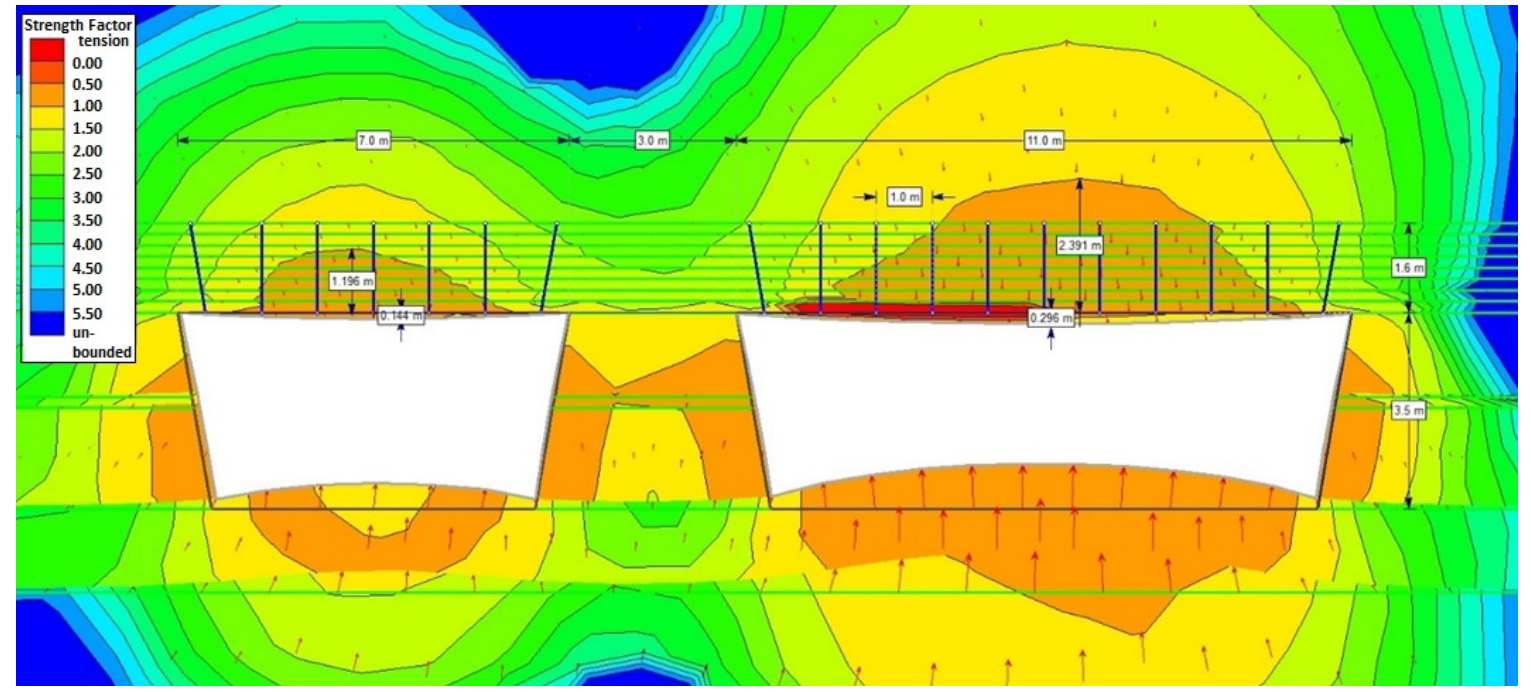

(e)

Figure 15. Maximal total displacement of roof rocks with net bolting $1 \mathrm{~m} \times 1 \mathrm{~m}$, for room and pillar width: (a) $7 \mathrm{~m} \times 7 \mathrm{~m}$; (b) $8 \mathrm{~m} \times 6 \mathrm{~m}$; (c) $9 \mathrm{~m} \times 5 \mathrm{~m}$; (d) $10 \mathrm{~m} \times 4 \mathrm{~m}$; (e) $11 \mathrm{~m} \times 3 \mathrm{~m}$.

In the numerical model it was assumed that the length of the rock bolt support was $1.6 \mathrm{~m}$. Based on the results of the range of rock damage area around the rooms (Table 2), it can be assumed that for the width of the expanded room, equal to $7 \mathrm{~m}$ and $8 \mathrm{~m}$, the expansion head of bolt which is $84 \mathrm{~mm}$ long, is located outside of the plastic (damage) area. The bolt support retains its functionality. For the width of the expanded room, equal to $9 \mathrm{~m}, 10 \mathrm{~m}$ and $11 \mathrm{~m}$, the expansion head is inside a damaged area, which may result in loss of bolt support functionality. In the adjacent room, on the other hand, the range of the rock damage area does not exceed $1.2 \mathrm{~m}$, which means that the bolt support is not exposed to overload and still retains its load capacity.

\section{Discussion of Results}

Using the results of laboratory tests, numerical modeling and a mathematical model of the collision of two masses, it is possible to determine the total impact energy $\left(\mathrm{E}_{\mathrm{i}}\right)$, according to Formula (6). It has been assumed in calculations that the mass $\mathrm{m}_{2}$, many times greater, is equal to the range of the rock 
destruction zone in the expanded roof of the room, while the mass $\mathrm{m}_{1}$ and the displacement of the bolt (d) are equal to the maximal total displacement. In addition, it was assumed in the calculations that the impact height $(h)$ of mass $m_{2}$, per mass $m_{1}$, is variable and ranges from $0.001 \mathrm{~m}$ to $0.05 \mathrm{~m}$. Figure 16 shows the dependence of the drop height and the corresponding impact energy for the expanded room.

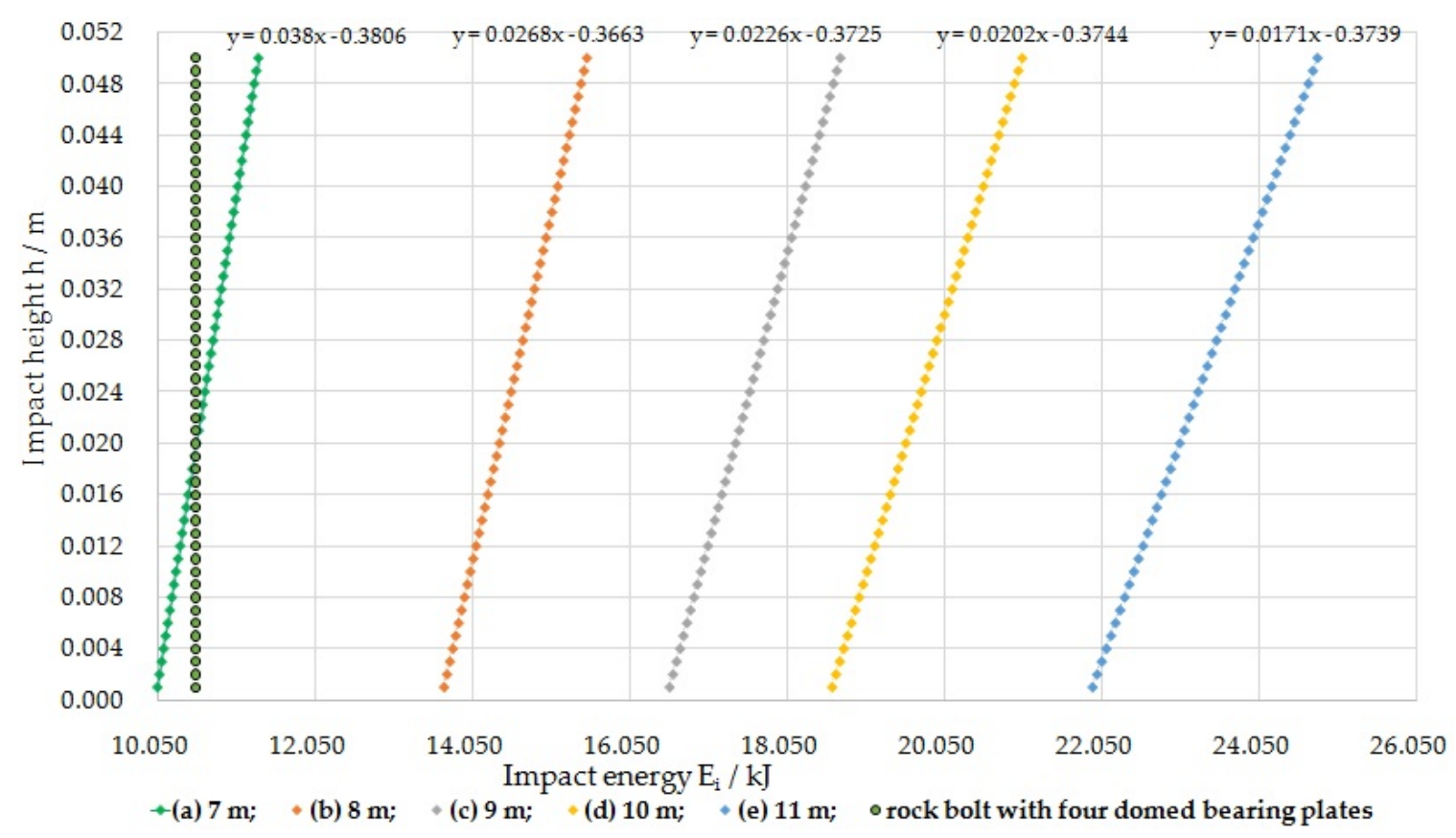

Figure 16. Impact energy for a variable height of drop of roof layer: (a) room and pillar with a width of $7 \mathrm{~m} \times 7 \mathrm{~m}$, respectively; (b) room and pillar with a width of $8 \mathrm{~m} \times 6 \mathrm{~m}$, respectively; (c) room and pillar with a width of $9 \mathrm{~m} \times 5 \mathrm{~m}$, respectively; (d) room and pillar with a width of $10 \mathrm{~m} \times 4 \mathrm{~m}$, respectively; (e) room and pillar with a width of $11 \mathrm{~m} \times 3 \mathrm{~m}$, respectively.

Based on Figure 16 and the total energy absorbed by the bolt support, shown in Figure 13, it can be concluded that for the width of the room and the pillar $(7 \mathrm{~m} \times 7 \mathrm{~m})$, only the bolt support with four dome bearing plates with a total height of $100 \mathrm{~mm}$ is able to brake the displacement rock layers, but only if the height of the mass impact $\mathrm{m}_{2}$ on the mass $\mathrm{m}_{1}$ does not exceed $18 \mathrm{~mm}$. Above this range, the bolt support may lose its functionality. For the other widths of rooms and pillars, the bolt support with a mechanical head with a diameter of $25.4 \mathrm{~mm}$ should be made of steel with a larger range of ductility. For an impact height of $18 \mathrm{~mm}$, the minimal deformation energy of the bolt support should be above $14.1 \mathrm{~kJ} ; 17.2 \mathrm{~kJ} ; 19.5 \mathrm{~kJ}$ and $23.1 \mathrm{~kJ}$, for room and pillar widths of $8 \mathrm{~m} \times 6 \mathrm{~m} ; 9 \mathrm{~m} \times 5 \mathrm{~m} ; 10 \mathrm{~m} \times 4 \mathrm{~m}$; $11 \mathrm{~m} \times 3 \mathrm{~m}$, respectively. Installation of the rock bolt support in mining excavations requires a change in its technology in the process of drilling bolt holes. First, a bolt hole should be made with a diameter equal to the diameter of the sleeve mechanical head (Figure 17a). In the second stage, the bolt hole at the roof should be widened to a diameter equal to the dome bearing plates (Figure 17b). The length of the widened bolt hole should be equal to the total height of the dome bearing plates. At the last stage, bolt support equipped with dome bearing plates, should be installed (Figure 17c) and pre-tensioned with a tightening torque of not less than $250 \mathrm{Nm}$. 


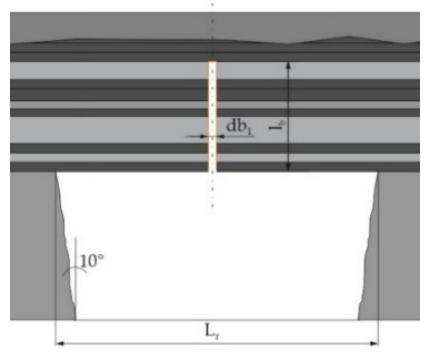

(a)

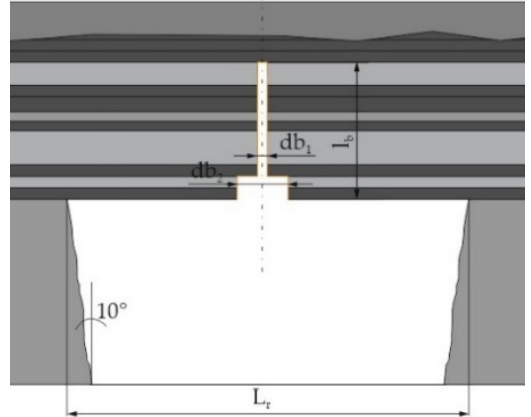

(b)

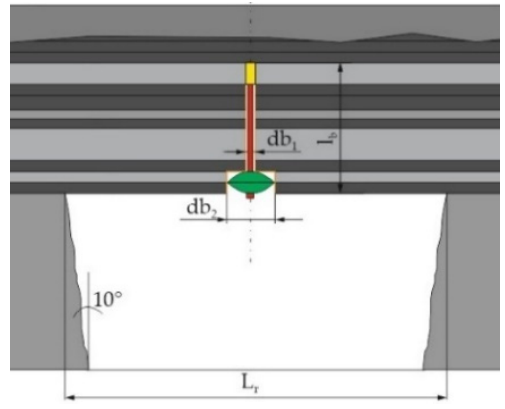

(c)

Figure 17. Stages of installing a mechanical bolt support with a sleeve head, equipped with dome bearing plates: (a) drilling the entire bolt hole (diameter $25.4 \mathrm{~mm}$ ); (b) widening the bolt hole at the roof by a length equal to the height of the dome bearing plates; (c) installing and pre-tensioning; Lr-room width; $\mathrm{db}_{1}$ - diameter of the bolt hole; $\mathrm{db}_{2}$ - diameter of the widened bolt hole; $\mathrm{l}_{\mathrm{b}}$-length of bolt hole.

From a technological point of view, the process of installing the bolt support will take more time. However, for low excavations up to $2 \mathrm{~m}$ in height, it is a practical solution that, on the one other hand, will allow free movement of self-propelled drilling and bolting mining machines, without fear that the bolt support will be damaged, while on the other, it will allow greater absorption of deformation energy.

\section{Conclusions}

Based on the laboratory tests, it can be concluded that:

- The amount of absorbed deformation energy for a $1.6 \mathrm{~m}$-long bolt support with a mechanical head with a diameter of $25.4 \mathrm{~mm}$ is $5.603 \mathrm{~kJ} ; 6.239 \mathrm{~kJ} ; 7.402 \mathrm{~kJ} ; 10.535 \mathrm{~kJ} ; 9.049 \mathrm{~kJ}$, respectively for: one flat bearing plate; one dome bearing plate, $25 \mathrm{~mm}$ high; two dome bearing plates, $50 \mathrm{~mm}$ high; four dome bearing plates, $100 \mathrm{~mm}$ high; six dome bearing plates, $150 \mathrm{~mm}$ high.

- The most deformation energy is absorbed by a bolt support equipped with four dome bearing plates with a total height of $100 \mathrm{~mm}$. The total energy of deformation is almost twice as high compared to a support equipped with a flat bearing plate.

- In order to absorb more energy by bolt support equipped with six dome bearing plates, it would be necessary to use a bolt rod with increased strength parameters, in particular, the yield strength of steel. Then the dome bearing plates, in the amount of six, would work in the full range of load-displacement characteristics, achieving full compression.

Based on the numerical tests for five variants of room and pillar width, it can be concluded that:

- For the room and pillar width $7 \mathrm{~m} \times 7 \mathrm{~m}$ and $8 \mathrm{~m} \times 6 \mathrm{~m}$, respectively, the range of the rock destruction zone in the expanded roof of the room is smaller than the length of the bolt support, which means that it is able to take over the load. For the other variants, i.e., for the width of the room and the pillar of $9 \mathrm{~m} \times 5 \mathrm{~m} ; 10 \mathrm{~m} \times 4 \mathrm{~m}$ and $11 \mathrm{~m} \times 3 \mathrm{~m}$, respectively, the support is in the stress relief zone and is exposed to damage.

- With increasing room width, the maximal total displacement increases, which for the room and pillar widths for $7 \mathrm{~m} \times 7 \mathrm{~m} ; 8 \mathrm{~m} \times 6 \mathrm{~m} ; 9 \mathrm{~m} \times 5 \mathrm{~m} ; 10 \mathrm{~m} \times 4 \mathrm{~m} ; 11 \mathrm{~m} \times 3 \mathrm{~m}$, are: $0.256 \mathrm{~m} ; 0.268 \mathrm{~m}$; $0.281 \mathrm{~m} ; 0.288 \mathrm{~m} ; 0.296 \mathrm{~m}$, respectively.

Only the room and pillar width of $7 \mathrm{~m} \times 7 \mathrm{~m}$, under geomechanical seismic events, a $1.6 \mathrm{~m}$-long rock bolt support with a mechanical head $25.4 \mathrm{~mm}$ in diameter, equipped with four dome bearing plates with a total height of $100 \mathrm{~mm}$, will be able to support the roof layers, but only up to a range of impact heights of rock masses equal to $18 \mathrm{~mm}$. Above this height, as well as for other widths, bolts with increased ductility should be used. The use of dome bearing plates in industrial conditions does not 
require changing the geometry of the bolt rod or steel grade. Only in the conditions of low excavations (up to $2 \mathrm{~m}$ ), it is required that the bolt hole at the roof should be widened in order to place dome bearing plates. For the stratified roofs that are typical, especially for Polish copper mines at LGOM, yielding devices can be used directly with rock bolt support, which can significantly improve the work safety factor.

Author Contributions: Conceptualization, K.S., W.K., and K.Z.; methodology, K.S., W.K., and K.Z.; software, K.S.; validation, K.S., W.K.; formal analysis, K.S., W.K., K.Z., and A.Z.; investigation, K.S., W.K., K.Z., and A.Z.; resources, K.S., W.K., and K.Z.; writing-original draft preparation, K.S., W.K., and K.Z.; writing-review and editing, K.S., W.K., and K.Z.; visualization, K.S. and A.Z.; supervision, K.S., W.K. All authors have read and agreed to the published version of the manuscript.

Funding: This paper was prepared as part of AGH's scientific subsidy, under number: 16.16.100.215.

Conflicts of Interest: The authors wish to confirm that there are no known conflicts of interest associated with this publication and there has been no significant financial support for this work that could have influenced its outcome.

\section{References}

1. Kaiser, P.K. Keynote address: Support of tunnels in burst prone ground-Toward a rational design methodology. In Rockburst and Seismicity in Mines; Young, R.P., Ed.; Balkema: Avereest, The Netherlands, 1993; pp. 13-26.

2. Wu, X.; Jiang, Y.; Guan, Z.; Wang, G. Estimating the support effect of energy-absorbing rock bolts based on the mechanical work transfer ability. Int. J. Rock Mech. Min. Sci. 2018, 103, 168-178. [CrossRef]

3. Skrzypkowski, K. A new design of support for burst-prone rock mass in underground ore mining. In E3S Web Conferences; EDP Sciences: Les Ulis, France, 2018; Volume 71, p. 00006. [CrossRef]

4. Morissette, P.; Hadjigeorgiou, J. Ground support design for dynamic loading conditions: A quantitative data-driven approach based on rockburst case studies. J. Rock Mech. Geotech. Eng. 2019, 11, 909-919. [CrossRef]

5. Skrzypkowski, K.; Korzeniowski, W.; Zagórski, K.; Dudek, P. Application of Long Expansion Rock Bolt Support in the Underground Mines of Legnica-Głogów Copper District. Stud. Geotech. Mech. 2017, 39, 47-57. [CrossRef]

6. Skrzypkowski, K.; Korzeniowski, W.; Zagórski, K.; Zagórska, A. Modified Rock Bolt Support for Mining Method with Controlled Roof Bending. Energies 2020, 13, 1868. [CrossRef]

7. Ortlepp, W.D.; Human, L.; Erasmus, P.N.; Dawe, S. Static and Dynamic Load Displacement Characteristics of a Yielding Cable Anchor-Determined in a Novel Testing Device. In Proceedings of the Sixth International Symposium on Rockburst and Seismicity in Mines Proceedings; Potvin, Y., Hudyma, M., Eds.; Australian Centre for Geomechanics: Perth, Australia, 2005; pp. 529-534.

8. St-Pierre, L.; Hassani, F.P.; Radziszewski, P.H.; Oullet, J. Development of a dynamic model for a cone bolt. Int. J. Rock Mech. Min. 2009, 46, 107-114. [CrossRef]

9. Li, C.C. A new energy-absorbing bolt for rock support in high stress rock masses. Int. J. Rock Mech. Min. Sci. 2010, 47, 396-404. [CrossRef]

10. Charette, F.; Plouffe, M. Roofex $®$-Results of Laboratory Testing of a New Concept of Yieldable Tendon. In emphProceedings of the 4th International Seminar on Deep and High Stress Mining; Potvin, Y., Ed.; Australian Centre for Geomechanics: Perth, Australia, 2007; pp. 395-404.

11. Varden, R.; Lachenicht, R.; Player, J.; Thompson, A.; Villaescusa, E. Development and implementation of the Garford Dynamic Bolt at the Kanowna Belle Mine. In 10th Underground Operators' Conference-Boom and Beyond; The Australasian Institute of Mining and Metallurgy, Ed.; The Australasian Institute of Mining and Metallurgy Launceston: Tasmania, Australia, 2008; pp. 95-104.

12. Wu, Y.K.; Oldsen, J. Development of a new yielding rock bolt-Yield-Lok bolt. In Proceedings of the 44th US Rock Mechanics Symposium and 5th US-Canada Rock Mechanics Symposium, 27-30 June 2010; American Rock Mechanics Association: Salt Lake City, UT, USA, 2010; pp. 1-6.

13. Wang, G.; Wu, X.; Jiang, Y.; Huang, N.; Wang, S. Quasi-static laboratory testing of a new rock bolt for energy-absorbing applications. Tunn. Undergr. Space Technol. 2013, 38, 122-128. [CrossRef] 
14. He, M.; Gong, W.; Wang, J.; Qi, P.; Tao, Z.; Du, S.; Peng, Y. Development of a novel energy-absorbing bolt with extraordinarily large elongation and constant resistance. Int. J. Rock Mech. Min. Sci. 2014, 67, $29-42$. [CrossRef]

15. He, M.; Gao, Y.; Yang, J.; Gong, W. An Innovative Approach for Gob-Side Entry Retaining in Thick Coal Seam Longwall Mining. Energies 2017, 10, 1785. [CrossRef]

16. Wu, X.; Jiang, Y.; Wang, G.; Gong, B.; Guan, Z.; Deng, T. Performance of a New Yielding Rock Bolt Under Pull and Shear Loading Conditions. Rock Mech. Rock Eng. 2019, 52, 3401-3412. [CrossRef]

17. Yokota, Y.; Zhao, Z.; Nie, W.; Date, K.; Iwano, K.; Koizumi, Y.; Okada, Y. Development of a new deformation-controlled rock bolt: Numerical modelling and laboratory verification. Tunn. Undergr. Space Technol. 2020, 98, 1-13. [CrossRef]

18. Hao, Y.; Wu, Y.; Ranjith, P.G.; Zhang, K.; Hao, G.; Teng, Y. A novel energy-absorbing rock bolt with high constant working resistance and long elongation: Principle and static pull-out test. Constr. Build. Mater. 2020, 243, 1-16. [CrossRef]

19. Lu, Y.; Wang, L.; Zhang, B. An experimental study of a yielding support for roadways constructed in deep broken soft rock under high stress. Min. Sci. Technol. 2011, 21, 839-844. [CrossRef]

20. Sun, X.; Wang, L.; Lu, Y.; Jiang, B.; Li, Z.; Zhang, J. A yielding bolt-Grouting support design for a soft-rock roadway under high stress; a case study of the Yuandian No. 2 coal mine in China. J. S. Afr. Inst. Min. Metall. 2018, 118, 71-82. [CrossRef]

21. Korzeniowski, W.; Skrzypkowski, K.; Zagórski, K. Reinforcement of Underground Excavation with Expansion Shell Rock Bolt Equipped with Deformable Component. Stud. Geotech. Mech. 2017, 39, 39-52. [CrossRef]

22. Chen, L.; Li, Q.; Yang, J.; Qiao, L. Laboratory Testing on Energy Absorption of High-Damping Rubber in a New Bolt for Preventing Rockburst in Deep Hard Rock Mass. Shock Vib. 2018, 6, 1-12. [CrossRef]

23. Dai, L.; Pan, Y.; Wang, A. Study of the energy absorption performance of an axial splitting component for anchor bolts under static loading. Tunn. Undergr. Space Technol. 2018, 81, 176-186. [CrossRef]

24. Dai, L.; Pan, Y.; Wang, A.; Xiao, Y.; Ma, X. Experimental study on the self-protection performance on Anchor Bolts with Energy-Absorbing Tails. Rock Mech. Rock Eng. 2019, 52, 1-15. [CrossRef]

25. Martino, J.B.; Chandler, N.A. Excavation-induced damage studies at the underground research laboratory. Int. J. Rock Mech. Min. Sci. 2004, 41, 1413-1426. [CrossRef]

26. Bastante, F.G.; Alejano, L.; Gonzalez-Cao, J. Predicting the extent of blast-induced damage in rock masses. Int. J. Rock Mech. Min. Sci. 2012, 56, 44-53. [CrossRef]

27. Guan, X.; Guo, C.; Mou, B.; Shi, L. Tunnel millisecond-delay controlled blasting based on the delay time calculation method and digital electronic detonators to reduce structure vibration effects. PLoS ONE 2019, 14, 1-25. [CrossRef] [PubMed]

28. State Mining Authority. Available online: http://www.wug.gov.pl/english (accessed on 13 February 2020).

29. Skrzypkowski, K. Evaluation of Rock Bolt Support for Polish Hard Rock Mines. In E3S Web of Conferences; EDP Sciences: Les Ulis, France, 2018; Volume 35, p. 01006. [CrossRef]

30. Małkowski, P.; Juszyński, D. The assessment of the roof fall hazard in Legnica-Glogow Copper District mining plant. Pol. Min. Rev. 2019, 1, 16-26.

31. Butra, J.; Dańda, Z.; Katulski, Z. Causes of roofs falling down and control methods in copper ore mines. Mag. State Min. Auth. Work Saf. Environ. Prot. Min. 1997, 6, 151-157.

32. Skrzypkowski, K. Roof bolting in terms of dynamic hazards. Miner. Resour. Manag. 2008, 24, 305-316.

33. Yugo, N.; Shin, W. Analysis of blasting damage in adjacent mining excavations. J. Rock Mech. Geotech. Eng. 2015, 7, 282-290. [CrossRef]

34. Mutke, G.; Masny, W.; Prusek, S. Peak particle velocity as an indicator of the dynamic load exerted on the support of underground workings. Acta Geodyn. Geomater. 2016, 13, 367-378. [CrossRef]

35. Mertuszka, P.; Fuławka, K.; Szumny, M.; Stolecki, L. The assessment of seismic effect of multi-face blasting in Polish copper mines conditions. Cuprum 2018, 3, 17-30.

36. Korzeniowski, W. Evaluation of State of Underground Gateroads and Rooms Based on Empirical Research Methods; AGH University of Science and Technology: Kraków, Poland, 2006; p. 96.

37. Skrzypkowski, K. Determination of the Stress-Strain Characteristics of Expansion Rock Bolt Support under Static and Dynamic Loads. Ph.D. Thesis, AGH University of Science and Technology, Faculty of Mining and Geoengineering, Kraków, Poland, 2014; p. 237. 
38. Korzeniowski, W.; Skrzypkowski, K.; Herezy, Ł. Laboratory Method for Evaluating the Characteristics of Expansion Rock Bolts Subjected to Axial Tension. Arch. Min. Sci. 2015, 60, 210-224. [CrossRef]

39. Niedbalski, Z.; Małkowski, P.; Majcherczyk, T. Monitoring of stand-and-roof-bolting support: Design optimization. Acta Geodyn. Geomater. 2013, 10, 215-226. [CrossRef]

40. Skrzypkowski, K.; Korzeniowski, W.; Zagórski, K.; Dominik, K.; Lalik, K. Fast, non-destructive measurement of roof-bolt loads. Stud. Geotech. Mech. 2019, 41, 93-101. [CrossRef]

41. MINOVA ARNALL Sp. z.o.o. Available online: http://www.arnall.com (accessed on 15 February 2020).

42. KGHM ZANAM S.A. Available online: https://www.kghmzanam.com (accessed on 12 February 2020).

43. Skrzypkowski, K. The influence of room and pillar method geometry on the deposit utilization rate and rock bolt load. Energies 2019, 12, 4770. [CrossRef]

44. Skrzypkowski, K.; Korzeniowski, W.; Zagórski, K.; Zagórska, A. Flexibility and load-bearing capacity of roof bolting as functions of mounting depth and hole diameter. Energies 2019, 12, 3754. [CrossRef]

45. Ansell, A. Dynamic testing of steel for a new type of energy absorbing rock Bolt. J. Constr. Steel Res. 2006, 62, 501-512. [CrossRef]

46. Skrzypkowski, K. Laboratory testing of a long expansion rock bolt support for energy-absorbing applications. In E3S Web of Conferences; EDP Sciences: Les Ulis, France, 2018; Volume 29, p. 00004. [CrossRef]

47. Małkowski, P. The impact of the physical model selection and rock mass stratification on the results of numerical calculations of the state of rock mass deformation around the roadways. Tunn. Undergr. Space Technol. 2015, 50, 365-375. [CrossRef]

48. Sepehri, M.; Apel, D.; Szymanski, J. Full three-dimensional finite element analysis of the stress redistribution in mine structural pillar. J. Powder Metall. Min. 2013, 3, 1-7. [CrossRef]

49. Rocscience. Available online: https://www.rocscience.com (accessed on 10 February 2020).

50. Hosseini, N.; Oraee, K.; Gholinejad, M. Seismic analysis of horseshoe tunnels under dynamic loads due to earthquakes. In 10th Underground Coal Operators' Conference; Aziz, N., Ed.; University of Wollongong \& the Australasian Institute of Mining and Metallurgy: Wollongong, Australia, 2010; pp. 140-145.

51. Noh, G.; Bathe, K.-J. An explicit time integration scheme for the analysis of wave propagations. Comput. Struct. 2013, 129, 178-193. [CrossRef]

(C) 2020 by the authors. Licensee MDPI, Basel, Switzerland. This article is an open access article distributed under the terms and conditions of the Creative Commons Attribution (CC BY) license (http://creativecommons.org/licenses/by/4.0/). 